\title{
The regional distribution of zeolites in the basalts of the Faroe Islands and the significance of zeolites as palaeo- temperature indicators
}

\author{
Ole Jørgensen
}

The first maps of the regional distribution of zeolites in the Palaeogene basalt plateau of the Faroe Islands are presented. The zeolite zones (thomsonite-chabazite, analcite, mesolite, stilbite-heulandite, laumontite) continue below sea level and reach a depth of $2200 \mathrm{~m}$ in the Lopra-1/1A well. Below this level, a high temperature zone occurs characterised by prehnite and pumpellyite. The stilbite-heulandite zone is the dominant mineral zone on the northern island, Vágar, the analcite and mesolite zones are the dominant ones on the southern islands of Sandoy and Suðuroy and the thomsonite-chabazite zone is dominant on the two northeastern islands of Viðoy and Borðoy. It is estimated that zeolitisation of the basalts took place at temperatures between about $40^{\circ} \mathrm{C}$ and $230^{\circ} \mathrm{C}$. Palaeogeothermal gradients are estimated to have been $66 \pm 9^{\circ} \mathrm{C} / \mathrm{km}$ in the lower basalt formation of the Lopra area of Suðuroy, the southernmost island, $63 \pm 8^{\circ} \mathrm{C} / \mathrm{km}$ in the middle basalt formation on the northernmost island of Vágar and $56 \pm 7^{\circ} \mathrm{C} / \mathrm{km}$ in the upper basalt formation on the central island of Sandoy.

A linear extrapolation of the gradient from the Lopra area places the palaeosurface of the basalt plateau near to the top of the lower basalt formation. On Vágar, the palaeosurface was somewhere between $1700 \mathrm{~m}$ and $2020 \mathrm{~m}$ above the lower formation while the palaeosurface on Sandoy was between $1550 \mathrm{~m}$ and $1924 \mathrm{~m}$ above the base of the upper formation.

The overall distribution of zeolites reflects primarily variations in the maximum depth of burial of the basalt rather than differences in heat flow. The inferred thinning of the middle and upper basalt formation from the central to the southern part of the Faroes is in general agreement with a northerly source area for these basalts, centred around the rift between the Faroes and Greenland. The regional zeolite distribution pattern is affected by local perturbations of the mineral zone boundaries that reflect local differences in the temperature, perhaps related to the circulation of water in the underground. The zonal distribution pattern suggests that these temperature anomalies are in part related to NW-SE-trending eruption fissures or zones of weakness separating the present islands and are subparallel to transfer zones in the Faroe-Shetland Basin. Both the regional and the local distribution of zeolite assemblages are probably a reflection of the basic volcanic-tectonic pattern of the Faroe Islands.

Keywords: Faroe Islands, Palaeogene basalt plateau, zeolite zone, palaeotemperature indicators

O.J., Scandinavian Asbestos \& Mineral Analysis, Kildeskovsvej 62,DK-2820 Gentofte,Denmark. E-mail: Oj@oj-sama.dk 
The zeolites of the Faroe Islands have been known for more than 300 years (Debes 1673) although the islands remained nearly unknown to mineralogists until the end of the eighteenth century. Because of increasing interest in mineralogy in the nineteenth century, the Faroe Islands were visited by many naturalists. One of these was Brewster (1825), who proposed the name levyne for a new zeolite species he discovered at Dalsnípa on Sandoy. The first modern description of the distribution of Faroese minerals was published by Currie (1905), who visited the Faroe Islands and described the minerals at 120 localities. Five years later a new description of the Faroese zeolites was presented by Görgey (1910). Interest in the minerals of the Faroe Islands declined during the following 70 years until Betz (1981) visited the islands and reviewed the classic localities. The present author started a literature study to discover, if a system of zeolite zones exists on the Faroe Islands similar to that described by Walker (1960) in East Iceland, but concluded that published descriptions were based on minerals from the same set of localities that were known to be rich in mineral species and where large crystals could be collected. This sampling bias meant that it was not possible to decide if zeolite zones existed on the Faroe Islands, so in 1979 a systematic mapping of the zeolites in the Faroe Islands was initiated by the present author. During the following 20 years, more than 800 localities were visited and about 3000 rock samples were investigated in the field and in the laboratory. The work was extended by studying samples from the Vestmanna- 1 and Lopra-1 boreholes drilled in 1980 and 1981, respectively (Jørgensen 1984; Waagstein et al. 1984). In 1996, the Lopra-1 borehole was deepened to a total of $3565 \mathrm{~m}$ (Lopra-1/1A) and the secondary minerals in the deepened part of the Lopra well were also described by the present author (Jørgensen 1997).

The aim of the present paper is to describe the secondary mineral distribution in the exposed parts of the Faroe Islands and in the Lopra-1/1A and Vestmanna-1 wells. The results of the mapping are used to estimate the palaeogeothermal gradients and the altitudes of the palaeosurfaces at various places in the Faroes basalt succession. The following topics will be discussed: (1) the general conditions for the use of zeolites as palaeotemperature indicators and the statistical distribution of zeolites in a vertical profile, (2) the original thickness of the three basalt formations and the volcanic evolution of the Faroese basalt complex, and (3) the regional distribution of the zeolite zones as a function of the thicknesses of the middle and the upper basalt formations.

\section{Outline of the geology of the Faroe Islands}

The Faroe Islands $\left(62^{\circ} \mathrm{N}, 7^{\circ} \mathrm{W}\right)$ have a total area of 1400 $\mathrm{km}^{2}$, an average height of $300 \mathrm{~m}$ above sea level and form part of the North Atlantic Brito-Arctic Cenozoic Igneous Province that extends from the British Isles to Greenland. The Faroe Islands consist almost exclusively of flood basalts that were erupted about 59-55 Ma (Waagstein 1988; Larsen et al. 1999).

The basalts on the exposed part of the Faroe Islands are divided into a lower, a middle and an upper basalt formation, separated by two horizons termed A and C in Fig. 1 (see also Fig. 4). According to Rasmussen \& Noe-Nygaard $(1969,1970)$ the volcanic evolution of the Faroe Islands may be summarised as follows: Volcanic activity started west of the present islands with the eruption of the lower basalt formation. With time the production rate of lava slowed to a temporary standstill. During this quiet period, about $10 \mathrm{~m}$ of clay and coal bearing sediments were deposited (the A-horizon.). Volcanic activity restarted with an explosive phase, resulting in the deposition of coarse volcanic ash and agglomerates. An effusive phase followed during which the middle basalt formation was erupted from

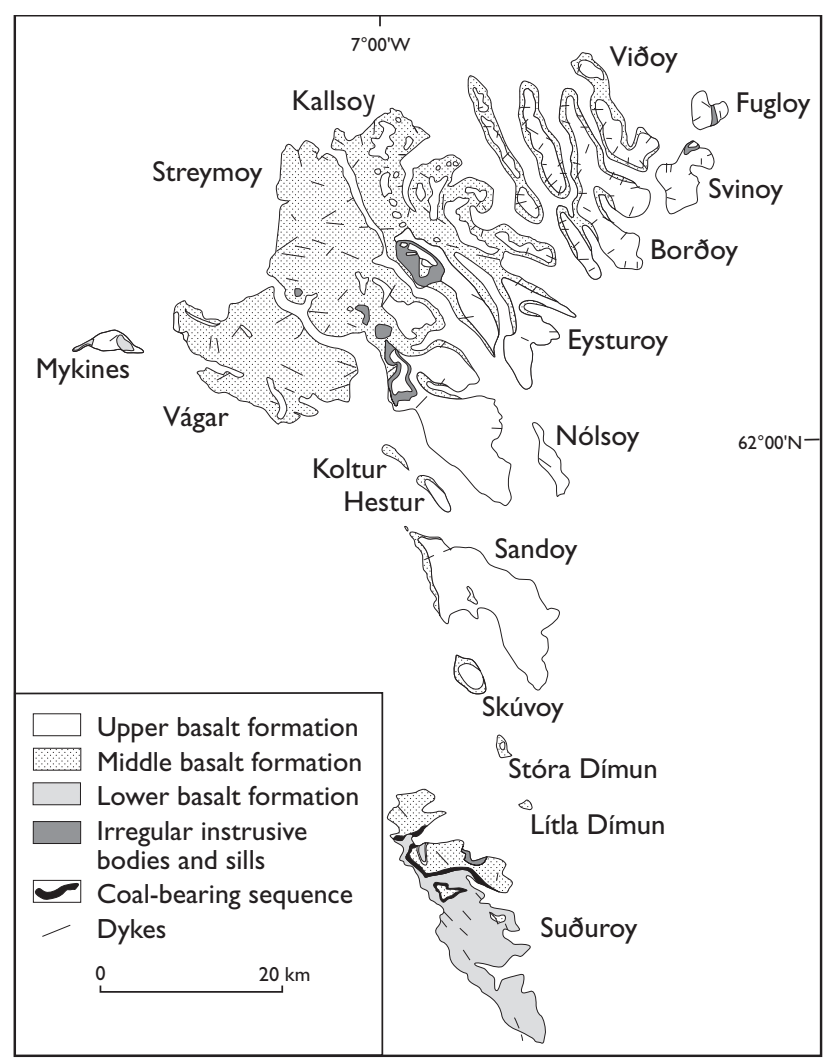

Fig. 1. Geological map of the Faroe Islands. From Rasmussen \& Noe-Nygaard (1969). 
several vents and small fissures within the present group of islands. Finally, volcanic activity moved farther east, away from the present islands, causing the lava flows of the upper basalt formation to transgress the middle basalt formation from the east. The discordant surface between the middle and upper basalt formations is named the $C$ horizon. After the upper basalt formation was formed, the basalt plateau was intruded by dykes and sills. Large sills were intruded near the boundary between middle and upper basalt formations in Streymoy and Eysturoy. Tectonic activity continued long after the volcanism ended until the Faroese basalt pile acquired its present gentle easterly dip.

\section{Methodology}

\section{Sampling and mineral identification}

Renewal of a large part of the road system of the Faroes just before initiation of the fieldwork made it possible to collect samples in fresh road cuts and new quarries along the roads. After most of the road sites had been examined, the mountains were traversed and samples collected along the old paths between the villages. In addition to the samples collected by the author, the present investigation is based on 500 specimens of Faroese zeolites collected privately by K. Jørgensen and on the collection of Faroese zeolites in the Geological Museum, Copenhagen.
The minerals were identified by their crystal morphology, optical properties, and X-Ray Diffraction (XRD) patterns or by chemical analysis carried out on a scanning electron microscope equipped with an energy dispersive analytical system. The XRD reference patterns were taken from Gottardi \& Galli (1985).

\section{Mapping of the mineral zones}

Walker $(1960,1970)$ defined his zeolite zones by seven distinctive amygdale mineral assemblages. Each zone was

Table 1. Abbreviations used for mineral names

\begin{tabular}{ll}
\hline An: analcite & Le: levyne \\
Ap: apophyllite & Me: mesolite: solid \\
Ca: calcite & Me*: mesolite: hair-like \\
Ce: celadonite & Mo: mordenite \\
Ch: chabasite & Na: natrolite \\
Cl: chlorite & Ok: okemite \\
Cld: chalcedony & Op: opal \\
Ed: epidote & Ph: phillipsite \\
Ep: epistilbite & Pr: prehnite \\
Ga: garronite & Pu: pumpellyite \\
Gi: gismondine & Qz: quartz \\
Gy: gyrolite & Sc: scolecite \\
Ha: harmotom & Sm: smectites \\
He: heulandite & St*: stellerite \\
La: laumontite & \\
\hline
\end{tabular}

\begin{tabular}{|c|c|c|c|c|c|c|c|c|c|c|c|c|c|c|c|c|c|c|c|c|c|c|c|c|c|}
\hline $\begin{array}{c}\text { Mineral } \\
\text { zones }\end{array}$ & $\begin{array}{c}\text { Approx. } \\
\text { temperatures } \\
\text { in }{ }^{\circ} \mathrm{C}^{\dagger} \\
\end{array}$ & $\mathrm{Ch}$ & $\mathrm{Th}^{*}$ & & An & $\mathrm{Me}^{*}$ & $\mathrm{Ph}$ & & $\mathrm{Me}$ & Gy & Mo & St & $\mathrm{He}$ & Ep & Ap & La & $\mathrm{Pr} P$ & $\mathrm{Ed}$ & $\mathrm{Cl}$ & $\mathrm{Ce}$ & Sm & & Cld & Op & $\mathrm{Ca}$ \\
\hline $\begin{array}{c}0 \\
\text { Zeolite free zone }\end{array}$ & $40-60$ & & & & & & & . & & & & & & & & & & & & & & & & & $\vdots$ \\
\hline $\begin{array}{c}1 \\
\text { Chabazite-thomsonite }\end{array}$ & $50-70$ & & & & & & ; & 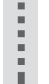 & & & & & & & & & & & & & & & & 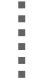 & 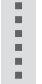 \\
\hline Analcite ${ }^{2}$ & & & & & 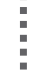 & & & & & 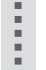 & & : & 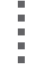 & & & & & & & & 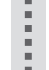 & $\vdots$ & 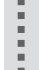 & & 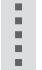 \\
\hline Mesolite ${ }^{3}$ & $90-100$ & 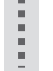 & & & & 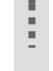 & 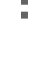 & & & 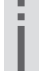 & & : & & ; & & 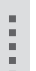 & & & 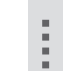 & & the & 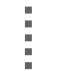 & 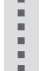 & & 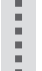 \\
\hline $\begin{array}{c}4 \\
\text { Stilbite-heullandite }\end{array}$ & 110-130 & & & & : & & & & & & & & & & & : & & & & & & & 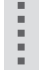 & & 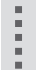 \\
\hline Laumontite & $190-230$ & & & : & & & & & " & I & & 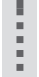 & & : & & & 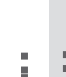 & & & & 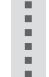 & & 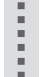 & & $\vdots$ \\
\hline $\begin{array}{l}\quad 6 \\
\text { High temperature zone }\end{array}$ & $>300$ & & & & & & & & & & & & & & & & & & & & ; & 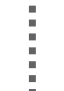 & 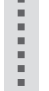 & & 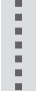 \\
\hline
\end{tabular}

† Source: Kristmannsdóttir \& Tómasson (1978), Kristmannsdóttir (1982) and Jakobsson \& Moore (1986)

Fig. 2. Mineral temperature scale. The five zeolite zones are defined by the index minerals chabasite + thomsonite, analcite, mesolite, stilbite + heulandite and laumontite. The temperatures are shown at zone boundaries. Abbreviations used for the various minerals are shown in Table 1. 
defined by the presence or dominance of certain mineral species, termed index minerals, whose names are used to designate the zones. In addition to the index minerals, other minerals may be present as indicated in Fig. 2. Walker's (1960) original zones are the carbonate, chabazitethomsonite, analcite, mesolite, laumontite, prehnite and epidote zones. The original mesolite zone was later subdivided into a mesolite and a stilbite-heulandite zone. This extended zone definition was adopted in the present investigation (Fig. 2). The classification of the zeolite zones was normally based on the mineral assemblages of amygdales, and fracture fillings were used only in places without amygdales.

Classification of the mineral assemblages from samples from the Lopra-1/1A and Vestmanna-1 boreholes was originally based on the abundance of the individual index minerals expressed as the weight $\%$ of the total mass of index minerals (Jørgensen 1984). In the present investigation, which is based on about 3000 samples, quantita- tive analysis was carried out only on two selected mineral assemblages, one from the middle and one from the upper basalt formation. The assemblages from most localities consist of a large number of minerals which makes it difficult to estimate the relative abundance of the different minerals. Another complication was the fact that more than one index mineral often occurred at the same locality. The present investigation is therefore based on the first formed index minerals in the amygdales, i.e. the minerals that were deposited nearest to the host rock. Where more than one first formed index mineral was present at a locality, the index mineral assumed to have the highest temperature of formation was chosen to map the zones. The mineral zones mapped in this way thus reflect the maximum temperature of mineralisation. This method is different from a mapping based on abundance of the minerals, which shows the distribution of the zeolite zones as the result of the main mineralisation. Appendices A and B give the observed paragenesis in the 29 sections and two

Table 2. Relative frequency (in \%) of amygdales and mineralised fractures in the exposed part of the Faroe Islands

\begin{tabular}{|c|c|c|c|c|c|c|c|c|}
\hline Mineral & Average & Suðuroy & Sandoy & Vágar & Streymoy & Eysturoy & Borðoy & Viðoy \\
\hline \multicolumn{9}{|l|}{ Zeolites: } \\
\hline Analcite & 32 & 61 & 16 & 49 & 33 & 35 & 18 & 15 \\
\hline Chabazite & 67 & 61 & 65 & 71 & 78 & 76 & 62 & 66 \\
\hline Cowlesite & 1 & 7 & 0 & 0 & 0 & 2 & 0 & 0 \\
\hline Epistilbite & $<1$ & 0 & 0 & 3 & 0 & 0 & 0 & 0 \\
\hline Garronite & 4 & 8 & 0 & 6 & 8 & 8 & 0 & 0 \\
\hline Gismondine & 4 & 0 & 10 & 0 & 5 & 8 & 3 & 0 \\
\hline Heulandite & 30 & 51 & 69 & 77 & 60 & 63 & 38 & 38 \\
\hline Laumontite & 11 & 5 & 6 & 29 & 29 & 3 & 5 & 0 \\
\hline Levyne & 17 & 5 & 16 & 23 & 20 & 26 & 8 & 20 \\
\hline Mesolite & 61 & 56 & 65 & 86 & 63 & 60 & 48 & 50 \\
\hline Mordenite & 8 & 12 & 0 & 14 & 8 & 19 & 0 & 0 \\
\hline Natrolite & 4 & 10 & 0 & 9 & 0 & 5 & 3 & 0 \\
\hline Scolecite & 1 & 2 & 0 & 0 & 0 & 3 & 0 & 0 \\
\hline Stellerite & 45 & 24 & 55 & 26 & 20 & 13 & 6 & 9 \\
\hline Stilbite & 37 & 37 & 10 & 74 & 38 & 39 & 33 & 26 \\
\hline Phillipsite & 8 & 17 & 6 & 3 & 3 & 11 & 10 & 15 \\
\hline Thomsonite & 64 & 59 & 45 & 60 & 60 & 75 & 73 & 79 \\
\hline \multicolumn{9}{|l|}{ Other minerals: } \\
\hline Apophyllite & 15 & 12 & 13 & 29 & 20 & 27 & 3 & 0 \\
\hline Calcite & 36 & 37 & 39 & 34 & 43 & 32 & 32 & 32 \\
\hline Celadonite & 19 & 15 & 13 & 11 & 38 & 27 & 14 & 15 \\
\hline Chlorite & 8 & 10 & 3 & 3 & 23 & 13 & 5 & \\
\hline $\mathrm{CSH}$ & 2 & 5 & 0 & 3 & 0 & 8 & 0 & 15 \\
\hline Gyrolite & 12 & 7 & 3 & 14 & 28 & 29 & 0 & 21 \\
\hline Smectites & 18 & 7 & 3 & 36 & 23 & 26 & 16 & \\
\hline Silica minerals & 19 & 29 & 6 & 14 & 20 & 19 & 25 & 41 \\
\hline \multicolumn{2}{|l|}{ Visited localities } & 160 & 85 & 148 & 302 & 235 & 52 & 41 \\
\hline
\end{tabular}

Abundant minerals in bold face, common minerals in italics and rare minerals in normal type face. CSH is calcium silicate hydrates. Silica minerals are opal, chalcedony etc. 

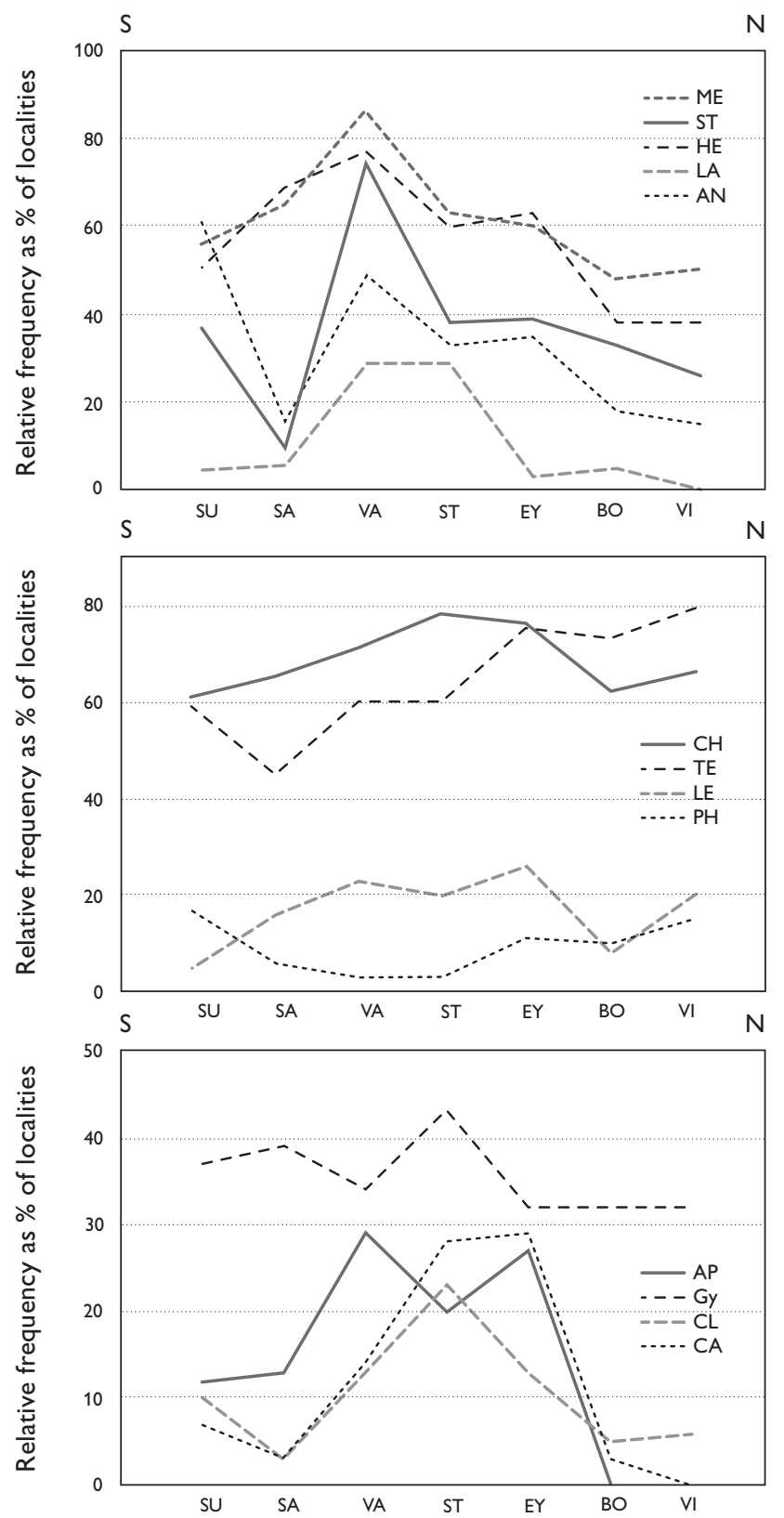

Fig. 3. Variation diagrams of the relative frequency of minerals on Suðuroy (SU), Sandoy (SA), Vágar (VÁ), Streymoy (ST), Eysturoy (EY), Borðoy (BO) and Viðoy (VI). Contractions for zeolite names are listed in Table 1.

wells mapped. The most probable temperature range of deposition of the zeolite zones is indicated in Fig. 2.

The rules of zone classification stated above could not be followed strictly everywhere. In the southern part of Suðuroy, mineralised vesicles are rare and, in this area, the mapping had to be based mainly on mineralised fractures. In the Lopra-1/1A borehole, the study was based on cuttings. They included fragments of amygdales and mineralised fractures, and the first formed index mineral could be determined only when part of the host rock adhered to the sample.

In order to establish a correlation between the zeolite zones and the temperature of formation of the minerals, the vertical distribution of index minerals and temperatures was examined in a number of boreholes in the geothermal areas of Iceland (Kristmannsdóttir \& Tómasson 1978; Kristmannsdóttir 1982). The result was the mineral-temperature scale shown in Fig. 2. Examination showed that the temperatures at the boundaries of individual zeolite zones varied from place to place. This is probably caused by the fact that zeolites can be formed within a broad range of temperatures and that variations in the chemical composition of the rock and the hydrothermal solutions can affect the formation temperature of the zeolites (Barth-Wirsching \& Höller 1989; Breck 1974). Another problem that makes it difficult to determine accurately the palaeotemperatures at the zone boundaries is the fact that zone boundaries are not well defined lines, a problem that will be discussed below. The temperatures at the boundaries of the zeolite zones are therefore indicated in Fig. 2 at the lowest and highest temperatures that occur at the Icelandic zone boundaries.

As mentioned above, the original classification of the mineral assemblages of the Lopra-1/1A and Vestmanna-1 drillholes was based on the most abundant index zeolite. It was therefore necessary to re-classify the mineral assemblages of the two drillholes according to the method used in the present investigation. This had a rather small effect on the zonation of the Lopra-1/1A drillhole. However, the first formed minerals from the Vestmanna-1 borehole are overgrown by abundant chabazite and thomsonite. Neglecting these later deposits, changes the zonation from a simple chabazite-thomsonite zone to an alternation between the mesolite and stilbite-heulandite zones.

\section{The distribution of minerals, zones and temperatures}

\section{Frequency of occurrence of minerals}

Table 2 shows the 17 zeolites and 8 associated minerals that were recorded in amygdales and mineralised fractures of the basalt in the islands of Suðuroy, Sandoy, Vágar, Streymoy, Eysturoy, Borðoy and Viðoy. In addition to the minerals listed, prehnite, pumpellyite, native copper and pyrite were found in the Lopra-1/1A borehole. All the zeolites listed in Table 2 have been reported previously from the Faroe Islands with the exception of garronite, 


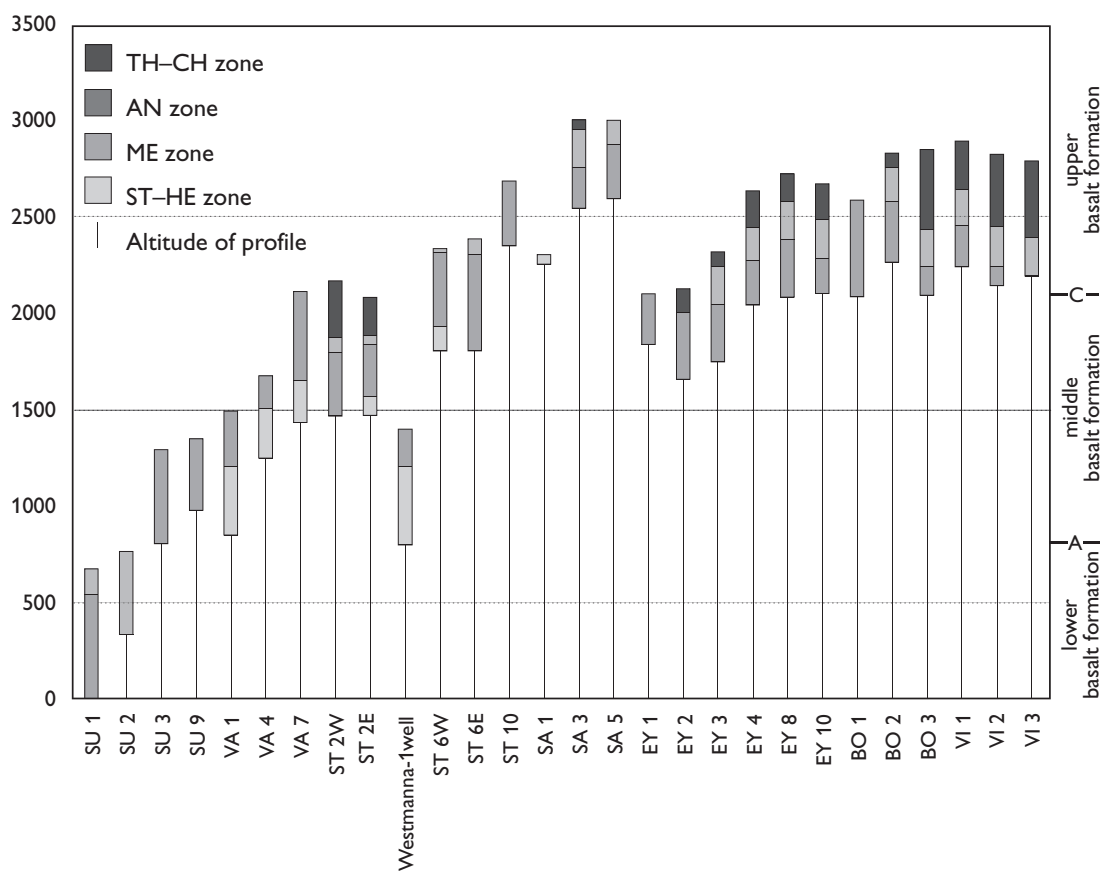

Fig. 4. Stratigraphic location of the zeolite zones in the 28 sections through the exposed part of the Faroe Islands. The data shown here are tabulated in Table 3.

which was found for the first time at several localities during the mapping reported here.

The minerals in Table 2 were divided into three classes: (1) very frequent minerals that occur at $60 \%$ or more of the localities; (2) common minerals that occur at between $15 \%$ and $60 \%$ of the localities; (3) rare minerals that occur at less than $15 \%$ of the localities. The frequency of occurrence is given as percentages of localities examined on each island.

From the column named average in Table 2 , it is seen that chabazite, mesolite and thomsonite are the most frequent secondary minerals within the exposed part of the Faroe Islands, followed by stilbite, stellerite, heulandite, analcite and calcite. Epistilbite and scolecite are rare minerals in the exposed part of the Faroe Islands, but they are common in the Lopra-1/1A well.

\section{Regional distribution of minerals and zones}

Fig. 3 shows how the relative frequency of a number of index minerals and associated minerals varies from island to island. For most of the minerals, the relative frequency decreases from south to north and from west to east, but for the minerals of the analcite and the chabazite-thomsonite zone, the relative frequency increases in the direction of Viðoy (Fig. 1). The variation in relative frequency of minerals reflects the regional shift in the distribution of mineral zones. The analcite and mesolite zones are the dominant mineral zones on Suðuroy. From Sandoy to Vágar, the analcite zone is gradually replaced by a stilbiteheulandite zone that becomes widespread on Vágar. On Streymoy and Eysturoy the stilbite-heulandite zone has a less widespread distribution, so that the stilbite-heulandite and the mesolite zones are of equal importance. The areal extent of the mesolite and stilbite-heulandite zones is further reduced on Borðoy and Viðoy, so the chabazitethomsonite zone becomes the major one on these two islands.

\section{Description of mineral assemblages and zones}

Figures 5-11 show the geographic distribution of the mineral zones on the islands Suðuroy, Sandoy, Vágar, Streymoy, Borðoy and Viðoy. In order to show the vertical distribution of the mineral zones, 28 local sections were constructed that are also shown on Figs 5-11. The sections have been arranged such that it is possible to follow the changes in the mineral zones both geographically and stratigraphically (Fig. 4). The data on which the sections are based are shown in Appendices A and B, and Table 3 gives the thickness of each zone.

In contrast to the profiles drilled by the Lopra-1/1A and Vestmanna-1 boreholes, the profiles from the exposed part of the Faroes have been constructed from observations along each section line, so the sections do not represent a single vertical profile through the lava pile. 
Table 3. Stratigraphic position and thickness of mineral zones (see Fig. 4)

\begin{tabular}{|c|c|c|c|c|c|}
\hline Section & $\begin{array}{l}\text { Base level } \\
\text { Stratigraphic } \\
\text { height in } \mathrm{m}^{*}\end{array}$ & $\begin{array}{l}\text { ST-HE zone } \\
\text { Thickness } \\
\text { in metres }\end{array}$ & $\begin{array}{l}\text { ME zone' } \\
\text { Thickness } \\
\text { in metres }\end{array}$ & $\begin{array}{l}\text { AN zone } \\
\text { Thickness } \\
\text { in metres }\end{array}$ & $\begin{array}{c}\mathrm{CH}-\mathrm{TH} \text { zone } \\
\text { Thickness } \\
\text { in metres }\end{array}$ \\
\hline SU1+LO & 0 & - & $530 \dagger$ & 180 & - \\
\hline SU2 & 330 & - & - & 430 & - \\
\hline SU5 & 798 & - & 480 & - & - \\
\hline SU9 & 970 & - & 373 & - & - \\
\hline VÁ1 & 842 & 350 & 300 & _ & - \\
\hline VÁ4 & 1241 & 250 & 180 & - & - \\
\hline VÁ7 & 1424 & 219 & 463 & - & - \\
\hline ST2W & 1461 & - & 325 & 82 & 293 \\
\hline ST2E & 1461 & 100 & 272 & 50 & 200 \\
\hline Vestmanna-1 & 795 & 400 & 200 & - & - \\
\hline ST6W & 1799 & 125 & 385 & 20 & - \\
\hline ST6E & 1799 & - & 500 & 83 & - \\
\hline ST10 & 2344 & - & 340 & - & - \\
\hline SA1 & 2252 & 50 & - & - & _- \\
\hline SA3 & 2545 & - & 200 & 200 & $4 \overline{6}$ \\
\hline SA5 & 2594 & - & 280 & 116 & _- \\
\hline EY1 & 1831 & 166 & 270 & - & - \\
\hline EY2 & 1650 & 50 & 350 & 125 & - \\
\hline EY3 & 1745 & - & 300 & 195 & $7 \overline{5}$ \\
\hline EY4 & 2039 & - & 230 & 170 & 193 \\
\hline EY8 & 2080 & - & 300 & 190 & 149 \\
\hline EY10 & 2098 & - & 180 & 200 & 187 \\
\hline BO1 & 2084 & - & 503 & - & - \\
\hline $\mathrm{BO} 2$ & 2263 & - & 310 & $1 \overline{82}$ & $7 \overline{0}$ \\
\hline $\mathrm{BO} 3$ & 2091 & - & 150 & 190 & 415 \\
\hline VI1 & 2237 & - & 100 & 190 & 251 \\
\hline $\mathrm{V} 12$ & 2140 & - & - & 208 & 375 \\
\hline VI3 & 2188 & - & & 200 & 400 \\
\hline
\end{tabular}

* Stratigraphic height within the exposed lava pile of the Faroe Islands.

$\dagger$ The mesolite zone is composed of the upper $330 \mathrm{~m}$ of the Lopra-1 mesolite zone plus the $200 \mathrm{~m}$ thick mesolite zone of section SU1.

\section{Suðuroy (Fig. 5)}

The distribution of the secondary minerals on Suðuroy is remarkably heterogeneous, a feature noted by Currie (1905). To the north of section SU2 that extends across the island from Fámjin to Holmssund, nearly all vesicles and fractures of the basalts are mineralised, but to the south of the section, amygdales and mineralised fractures are rare.

The boundary (section SU2) between the two parts of Suðuroy forms a transition zone in which the scattered vesicles are partly mineralised by an analcite assemblage composed of hair-like mesolite, thomsonite, analcite, chabazite, calcite, quartz and chalcedony. This mineral assemblage is found all along section SU2, which means that no relationship exists between the secondary minerals and their stratigraphic position within the lava pile.

To the north of section SU2, the number of mineral species and the degree of mineralisation increases gradu- ally northwards and the area just north of Trongisvágsfjørður is in the mesolite zone. Despite apparent regularity, the northern part of Suðuroy is a mosaic of small areas in which the mineral assemblages vary from place to place. The largest area of this kind occurs around the summit of Gluggarnir $(443 \mathrm{~m})$. At this locality, nearly all minerals listed in Table 2 are present.

The southern part of the island is partly devoid of zeolites. The most abundant minerals are quartz, calcite and chalcedony, while mesolite, thomsonite, chabazite, analcite, heulandite and stilbite are less frequent. The mode of mineralisation is also different on the two parts of the island. On the northern part of Suðuroy, mineralised fractures and vesicles occur in equal numbers, whereas mineralised fractures are more common than amygdales on the southern part of the island, in spite of the fact that empty vesicles occur at many localities. Because of this, section SU1 is based mainly on mineralised fractures.

Despite the weak amount of mineralisation on south- 

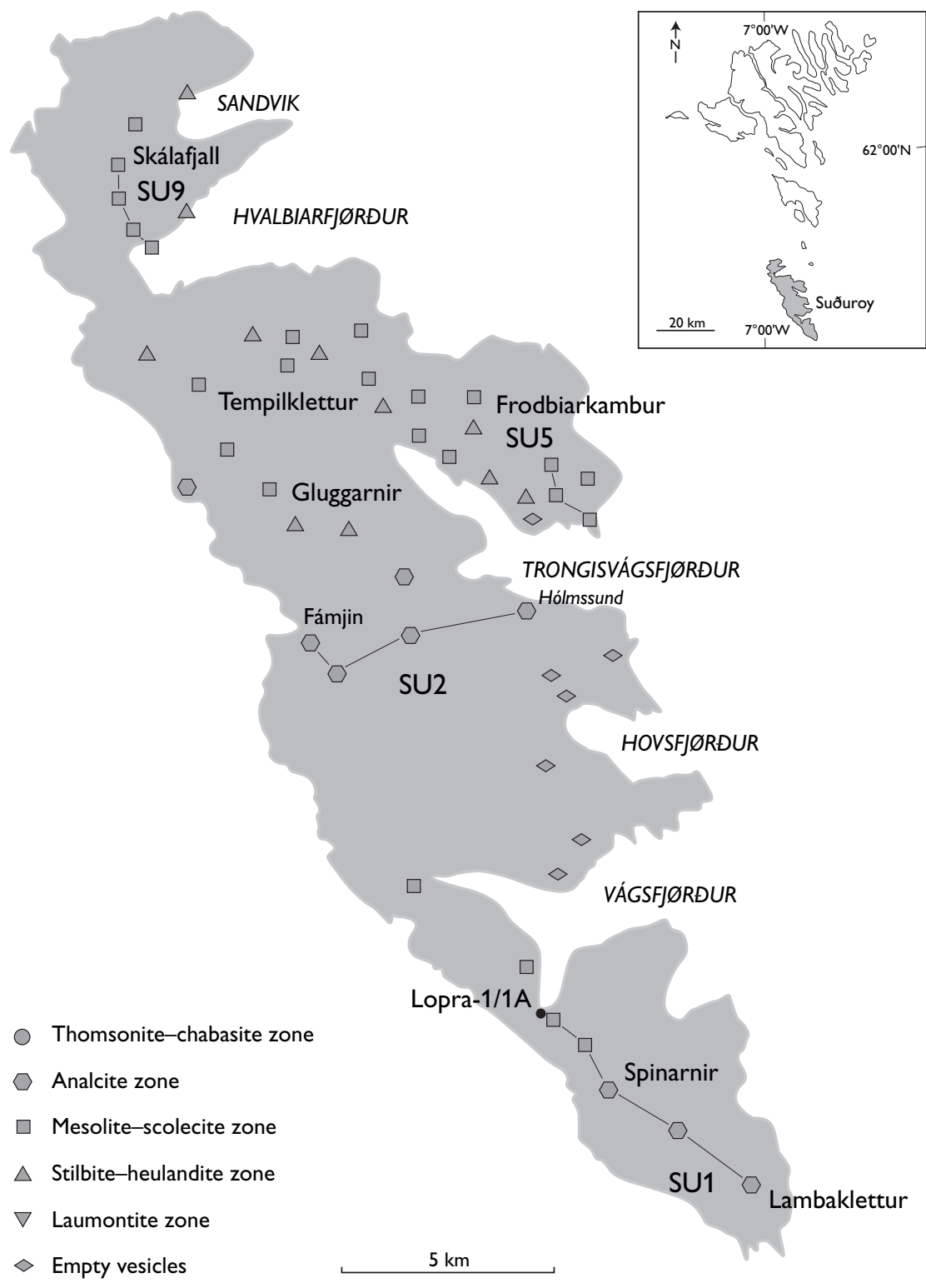

Fig. 5. Distribution of zeolite zones on Suðuroy and on sections SU1, SU2, SU5, SU9 and in the Lopra-1/1A borehole.

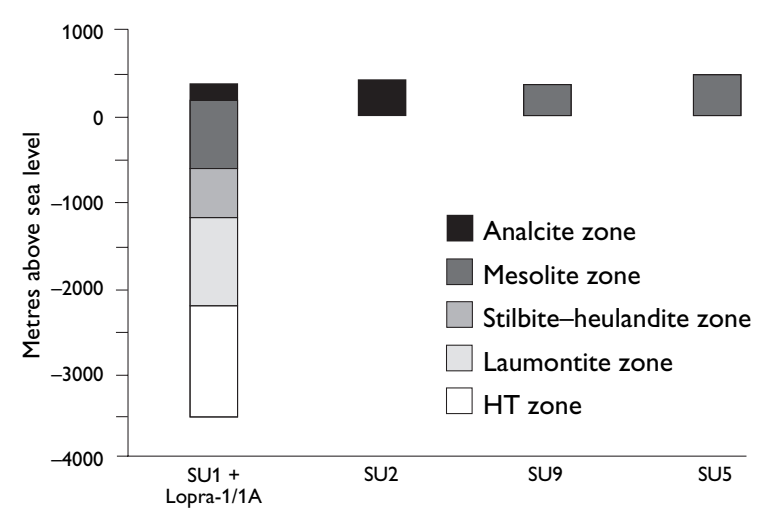


Fig. 6. Distribution of zeolite zones on Sandoy and on sections SA1, SA3 and SA5. The arrow indicates the apparent dip of the zeolite zones on section SA3.
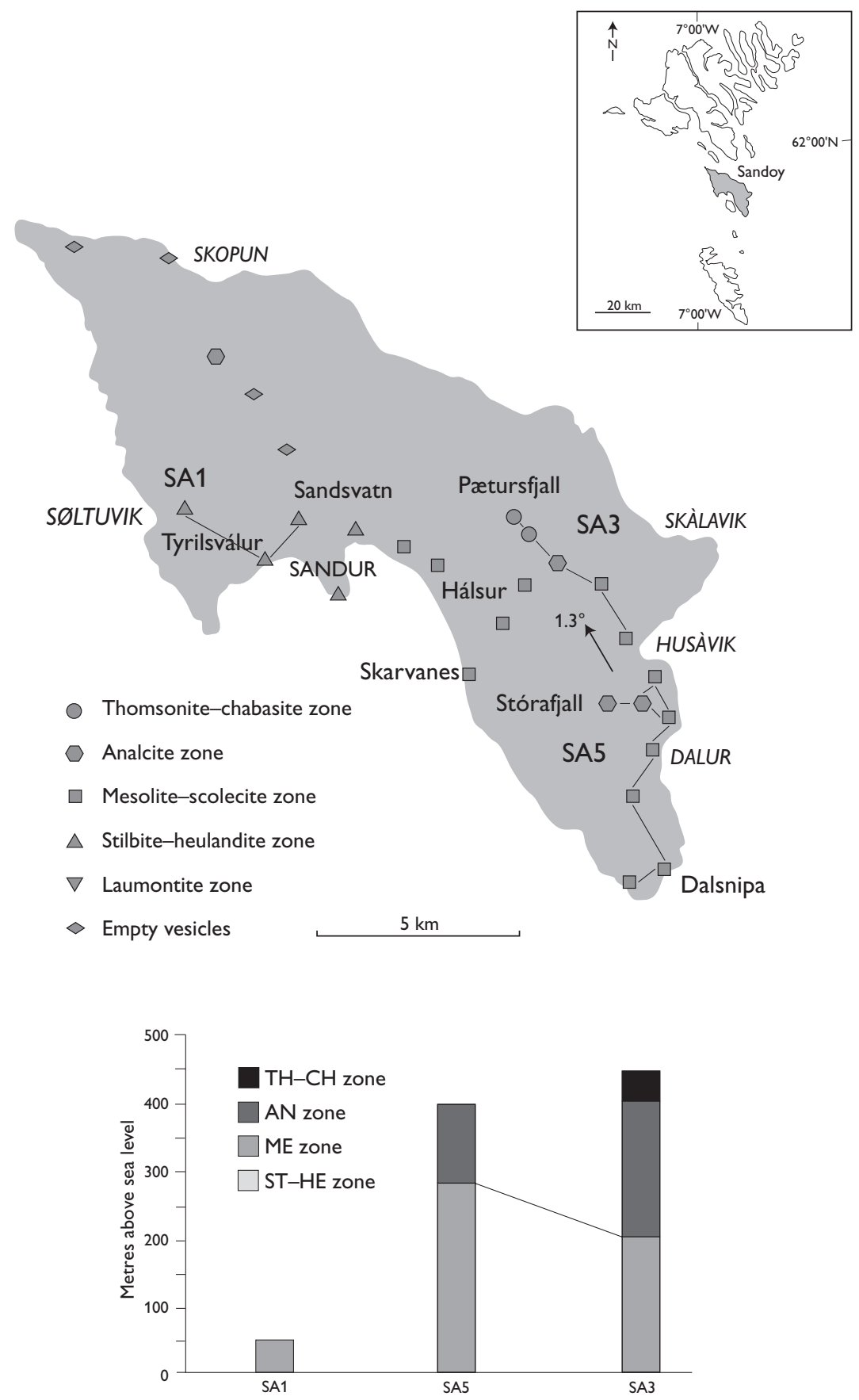

ern Suðuroy, a clear zonation can nevertheless be discerned along section SU1, where a $200 \mathrm{~m}$ mesolite zone is overlain by a $180 \mathrm{~m}$ analcite zone. The mesolite zone continues to a depth of $600 \mathrm{~m}$ below sea level in the Lopra-1/1A borehole (Fig. 5). The most abundant minerals there are mesolite, scolecite, stilbite, heulandite and mordenite. Chlorite, mesolite and scolecite were deposited first. Mesolite and scolecite are replaced by laumontite as the first formed mineral at a depth of $-626 \mathrm{~m}$, indicating the top of the stilbite-heulandite zone. At about $-1200 \mathrm{~m}$, epis- tilbite replaces stilbite as the first formed mineral so that the order of deposition becomes celadonite/chlorite-epistilbite-thomsonite-laumontite or celadonite/chlorite-epistilbite-laumontite-stilbite. Since an epistilbite zone has not yet been defined elsewhere, it was decided to include the total interval between $-1200 \mathrm{~m}$ and $-2200 \mathrm{~m}$ depth in the laumontite zone. A high temperature assemblage of laumonite, mordenite-prehnite, pumpellyite, chlorite, calcite and quartz is found from about $-2200 \mathrm{~m}$ to the bottom of the Lopra-1A borehole at $-3534 \mathrm{~m}$. 


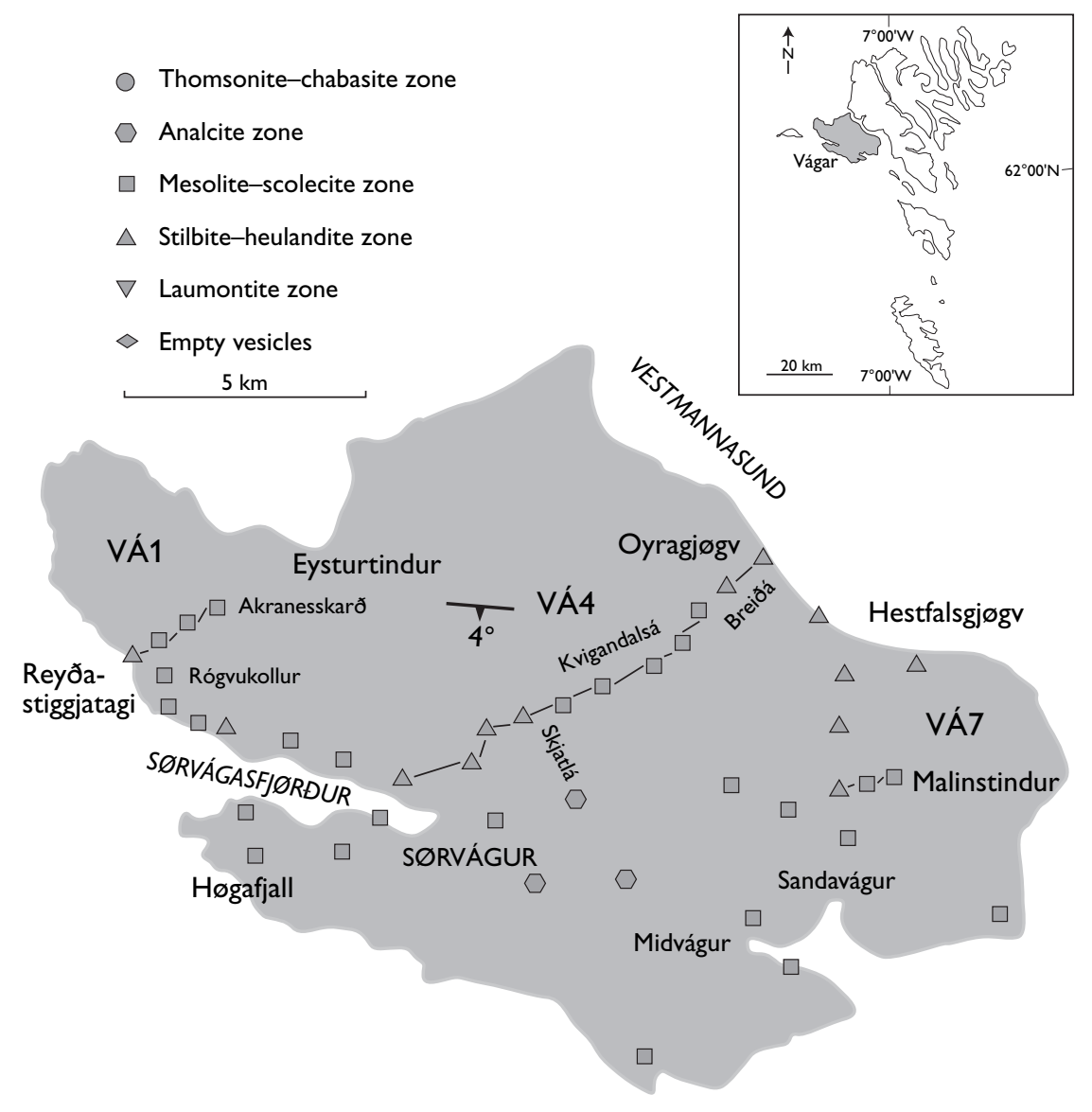

Fig. 7. Distribution of zeolite zones on Vágar and on sections VÁ1, VÁ4 and VÁ7. The dip and strike of the zeolite zones is indicated on the map.

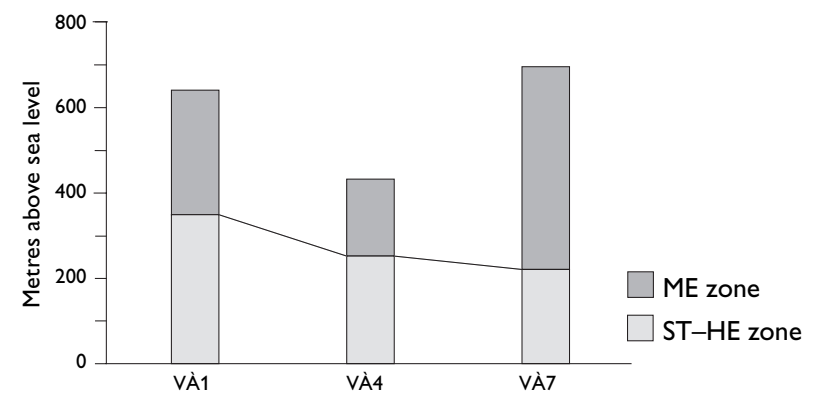

The uppermost mineral zone preserved in the SU1 section is part of an analcite zone. In East Iceland, a chabazitethomsonite zone (Walker 1960) and in East Greenland a zeolite free zone (Neuhoff et al. 1997) has been recorded in the uppermost parts of the basalt complexes whose total thicknesses are $700 \mathrm{~m}$ and $1400 \mathrm{~m}$, respectively. If equivalent zones have ever existed on the southern part of SuJuroy, they must have been considerably thinner than those on Iceland and Greenland, because the palaeosurface of the lower basalt formation was about $300 \mathrm{~m}$ above the Ahorizon (see below).

\section{Sandoy (Fig. 6)}

The southern part of Sandoy is strongly mineralised while the mineralisation in the northern part is weak. The area north of a line from Søltuvík to Skálavík is weakly mineralised by quartz, calcite, chalcedony, chabazite, hair-like mesolite, thomsonite and late formed stilbite or stellerite. Nearly all fractures and vesicles are totally mineralised to the south of the line. The most abundant zeolites are analcite, chabazite, heulandite, mesolite, stilbite and thomsonite. No distinct boundary has been observed between the northern and the southern part of the island.

Sections SA1, SA3 and SA5 (Fig. 6) show that four 
zeolite zones exist on Sandoy. In the area between Sandur and Søltuvik, the uppermost $50 \mathrm{~m}$ of a stilbite-heulandite zone are exposed. The stilbite-heulandite assemblage consists of chlorite, heulandite, stilbite, mordenite and occasionally of laumontite and apophyllite. The latter two minerals occur mostly in fractures in the basalt.

However, the degree of mineralisation is low in the stilbite-heulandite zone and, by volume, only half of the vesicles are mineralised.

The southern and the eastern parts of Sandoy are dominated by a mesolite zone. The most abundant minerals are chabazite, heulandite, mesolite (solid or hair-like), stellerite, thomsonite and calcite together with minor gyrolite, gismondine and levyne. Heulandite and mesolite are the first deposited minerals. Dalsnípa at the south-east coast of Sandoy is the type locality of levyne (Brewster 1825). A detailed quantitative analysis of the mineral assemblage and the zeolite zones in section SA3 is given below.

\section{Vágar (Fig. 7)}

In contrast to Suðuroy and Sandoy, Vágar is totally mineralised and the island may be divided into two areas. Northeast of a line from Sørvágur to Sandavágur, a stilbite-heulandite assemblage occurs at $40 \%$ of the localities that has not been observed farther south. South-east of the boundary line, the localities are dominated by a mesolite and analcite assemblage. Around Miðvágur hair-like mesolite with up to $100 \mathrm{~mm}$ long crystal needles can be found in larger fractures and cavities in the basalt.

The distribution pattern of the mineral assemblages on Vágar is controlled by the rise of the stilbite-heulandite zone towards the north-east. A calculation shows that the stilbite-heulandite zone dips from between $1-3^{\circ} \mathrm{SSW}$ to $0.6^{\circ} \mathrm{ESE}$, while the basalt flows dip $3-4^{\circ} \mathrm{ESE}$, i.e. the mineral zones are discordant to the lava stratification.

A quantitative analysis of the mineral assemblage and the zeolite zones on section VÁ1 is given below.

\section{Streymoy (Fig. 8)}

Streymoy can be divided into a northern, a central and a southern area. A stilbite-heulandite assemblage occurs along the coast from Tjørnuvík to Langasandur in the north. The observed minerals are stilbite, heulandite, thomsonite, compact mesolite, laumontite, gyrolite, okenite, tobermorite, apophyllite, celadonite and smectite. The mineral assemblage in the amygdales changes gradually towards the west. The hydrated calcium silicates, stilbite and laumontite, disappear from the amygdales although they still occur in fractures in the basalt. At Saksun near the north-west coast, the stilbite-heulandite assemblage is replaced by a mesolite assemblage, characterised by solid mesolite, thomsonite, heulandite, chabazite, calcite and montmorillionite. Gyrolite and stilbite are present, but only in fractures. The distribution pattern is reversed in the central part of Streymoy (between Langasandur, Vestmanna, Dalsnipa and Kollafjørður). There the stilbiteheulandite assemblage occurs along the west coast from Vestmanna to Dalsnipa, while a mesolite assemblage is found along the east coast between Langasandur and Kollafjørður.

Only the mesolite assemblage is found in the southern part of Streymoy. Because of the differences in mineral distribution, sections ST2 and ST6 have been divided into two columns, showing the eastern and the western parts of the sections, respectively (Fig. 8). The dip of the zeolite zones in the northern part of Streymoy is $2^{\circ} \mathrm{SW}$ and $2^{\circ} \mathrm{NNE}$ the central area.

The distribution of secondary minerals is rather complex at many localities in northern and central Streymoy and shows repetitive zoning, i.e. a regular repetition of two mineral zones. For example, on the path from Saksun to the summit of Borgin $(643 \mathrm{~m})$, a mesolite zone is first encountered, then a stilbite-heulandite zone, then, near the summit, a second mesolite zone. Repetitive zoning has also been observed at Loysingafjall $(638 \mathrm{~m})$, where the mesolite zone is overlain by a stilbite-heulandite zone, and along the main road between the villages of Vestmanna and Kvívík. Between Vestmanna and Kvívík, zones occur within which the vesicles and fractures of the basalt flows are mineralised, either by heulandite, stilbite, mordenite plus minor laumontite, or by compact mesolite, heulandite, stilbite, thomsonite and chabazite. The widths of the zones are from a few hundred metres to about $1 \mathrm{~km}$.

Repetitive zoning also exists in the Vestmanna-1 borehole. The first classification of the Vestmanna-1 mineral assemblages was based on the mass concentration of major index minerals. Since chabazite and thomsonite are the most abundant minerals, the entire mineral assemblage was classified as a thomsonite-chabazite assemblage. During the reclassification based on the first formed minerals for the present work, it became apparent that the drilled lava succession contains a repetitive zoning of mesolite and stilbite-heulandite assemblages (Fig. 8).

It is unlikely that repetitive zoning is caused by vertical fluctuations of the geothermal gradient within such relatively short distances, but the repetitive zoning may reflect flows of water of different temperature that changed 


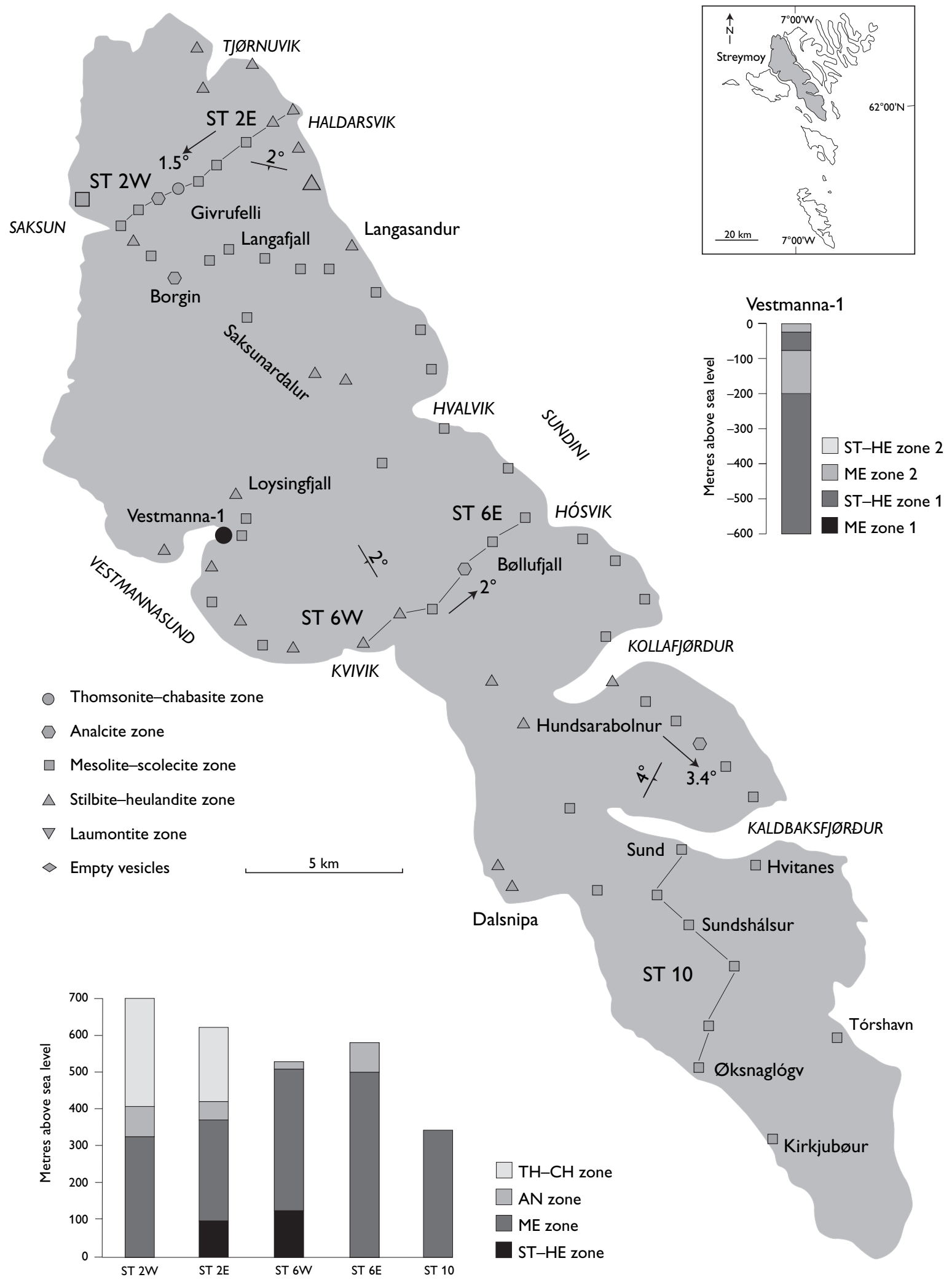

Fig. 8. Distribution of zeolite zones on Streymoy and on sections ST2E, ST2W, ST6E, ST6W, ST10 and in the Vestmanna-1 borehole. The dip and strike of the zeolite zones is indicated on the map. The arrows indicate the calculated strike of the zeolite zones between the sections. 
Fig. 9. Distribution of zeolite zones on Eysturoy and on sections EY1, EY2, EY3, EY8 and EY10. The dip and strike of the zeolite zones is indicated on the map. The arrows indicate the calculated dip of the zeolite zones between the sections.
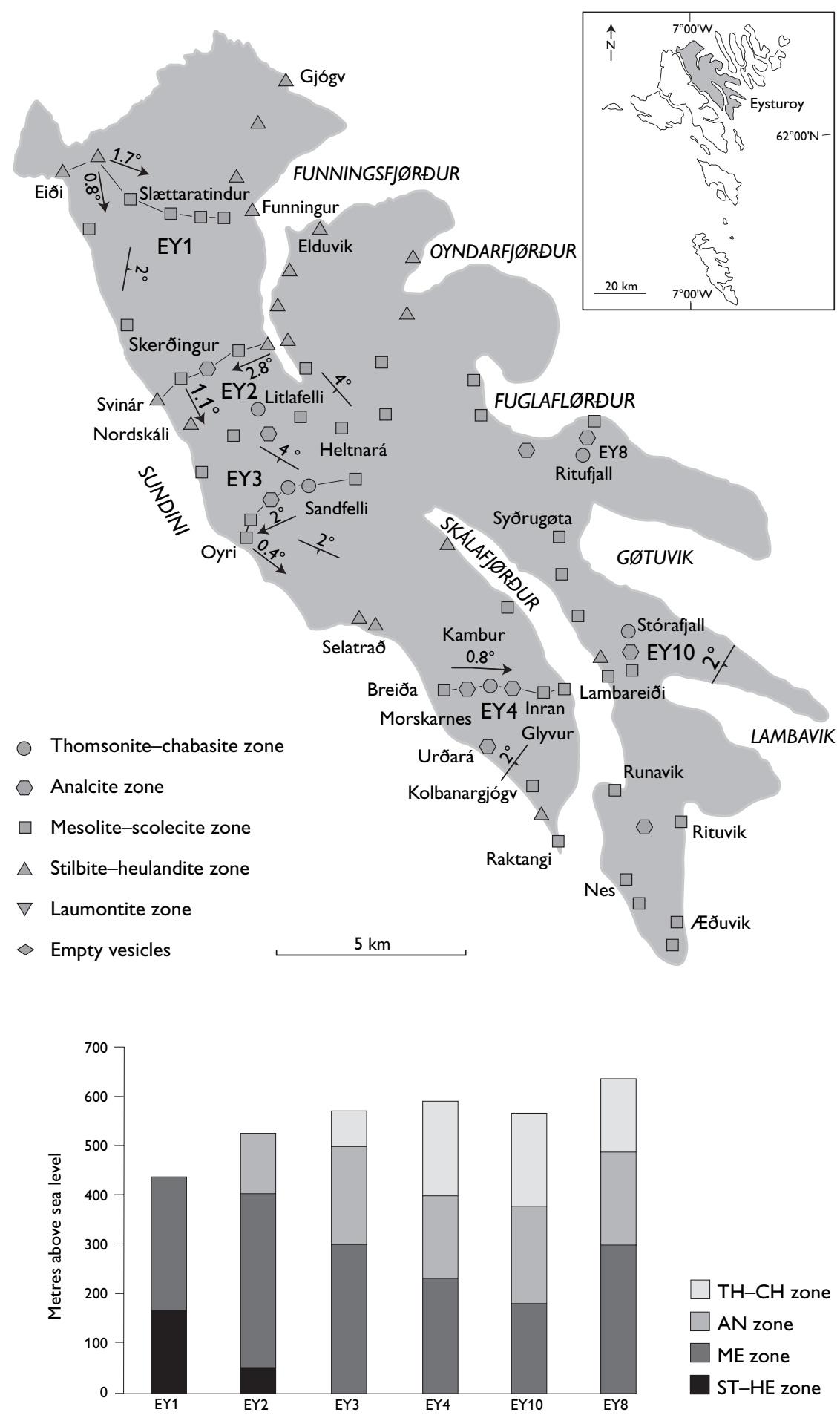

locally the vertical distribution of temperature. Alternative explanations for repetitive zoning are: (1) local variations in the chemical composition of the basalt, or: (2) mineralisation in an open and closed system, caused by variations in the percolation speed of the geothermal water (Barth-Wirsching \& Höller 1989; Gottardi 1989).

\section{Eysturoy (Fig. 9)}

Eysturoy may be divided into two for descriptive purposes. North of a line from Norðskáli to Fuglafjørður, the stilbite-heulandite assemblage occurs at $64 \%$ of localities. South of that line mineral assemblage occurs at only $12 \%$ of the localities (Fig. 9). The actual strike and dip of the 


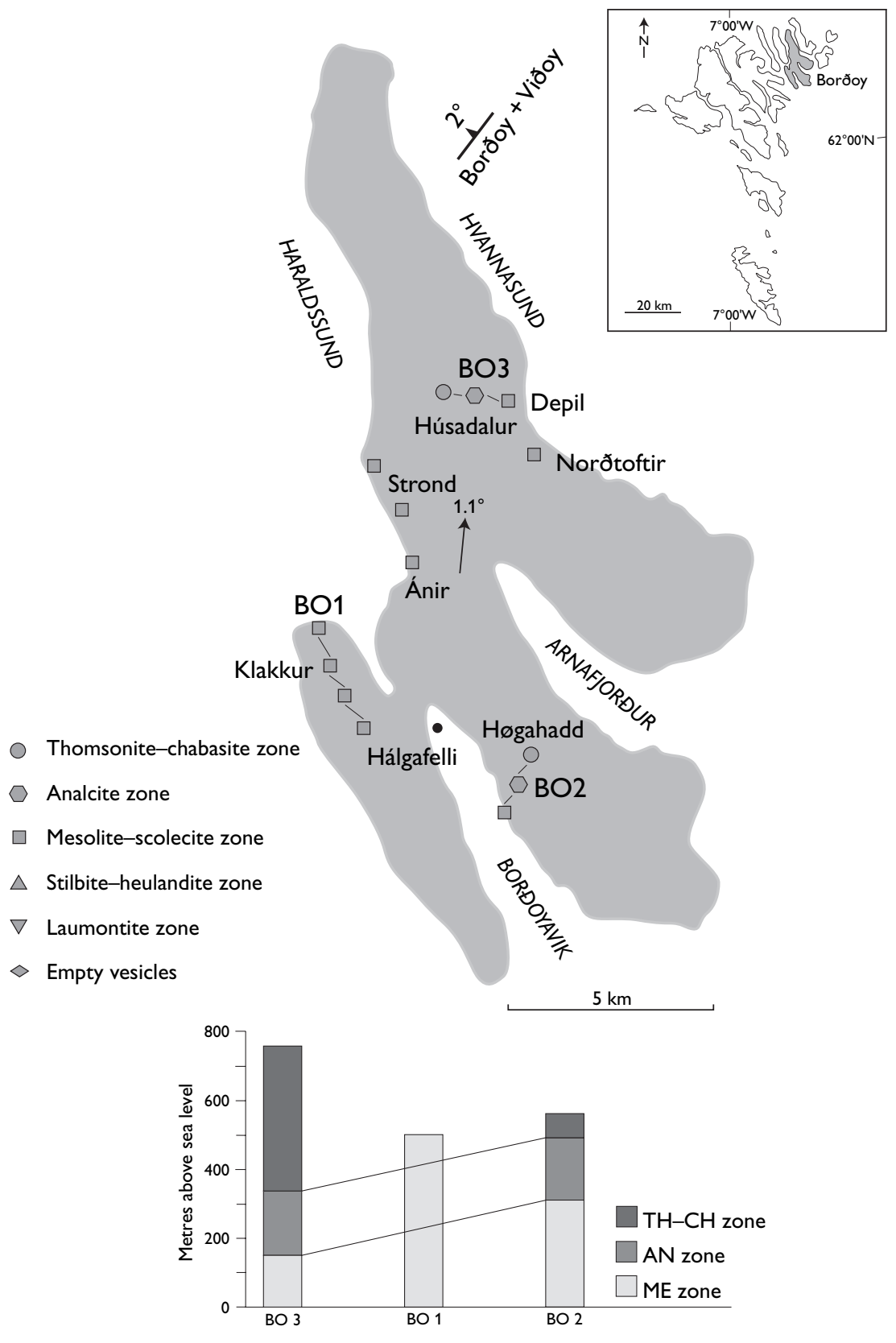

Fig. 10. Distribution of zeolite zones on Borðoy and on sections BO1, BO2 and $\mathrm{BO} 3$. The arrow shows the strike of the zeolite zones between $\mathrm{BO} 2$ and $\mathrm{BO} 3$. The common dip and strike of the zeolite zones on Borðoy and Viðoy is shown in the upper right corner.

zeolite zones can be determined by combining the dip of the zeolite zones along the sections with the dips between them. On Fig. 9 it can be seen that the strikes and dips change to follow the changes in mineralogy. North of a line from Svinár/Norðskáli to Fuglafjørður, the zeolite zones dip about $2^{\circ}$ towards the east. To the south of the line, the dips of the zones shift gradually from $4^{\circ}$ to the $\mathrm{SW}$ to $2^{\circ}$ to the $\mathrm{S}$. This means that the mineral zones are discordant to the lava bedding on the northern part of Eysturoy, but nearly concordant to it on the southern part of the island.

\section{Borðoy (Fig. 10)}

The mesolite, analcite and chabazite-thomsonite zones are the only ones exposed on Borðoy. At Klakkur (section $\mathrm{BO} 1)$ the vesicles and fractures in the basalt are mineralised by heulandite, stilbite, mesolite (massive and hairlike), thomsonite (massive and hair-like), chabazite, levyne, phillipsite, montmorillionite and celadonite, but no clear relationship exists between the distribution of mineral and height in the lava pile. Since analcite and mesolite are the first deposited minerals in most vesicles, the mineral assemblage of section $\mathrm{BO} 1$ was classified as a mesolite zone assemblage. The poor zoning west of Borðoyavik suggests 
Table 4. Quantitative analysis of section SA3, Sandoy. The table shows the number of observed and calculated amygdales containing the index mineral per 25 amygdales

\begin{tabular}{|c|c|c|c|c|c|c|c|c|c|c|c|c|}
\hline \multirow{2}{*}{$\begin{array}{l}\text { Altitude } \\
\text { metres }\end{array}$} & \multicolumn{2}{|c|}{$\mathrm{Me}$} & \multicolumn{2}{|c|}{$M e^{*}$} & \multicolumn{2}{|c|}{ Th } & \multicolumn{2}{|c|}{ Th* } & \multicolumn{2}{|c|}{ An } & \multicolumn{2}{|c|}{$\mathrm{Ch}$} \\
\hline & $\mathrm{N}_{\text {obs }}$ & $\mathrm{N}_{\mathrm{cal}}$ & $\mathrm{N}_{\text {obs }}$ & $\mathrm{N}_{\mathrm{cal}}$ & $\mathrm{N}_{\text {obs }}$ & $\mathrm{N}_{\mathrm{cal}}$ & $\mathrm{N}_{\text {obs }}$ & $\mathrm{N}_{\mathrm{cal}}$ & $\mathrm{N}_{\text {obs }}$ & $\mathrm{N}_{\mathrm{cal}}$ & $\mathrm{N}_{\text {obs }}$ & $\mathrm{N}_{\mathrm{cal}}$ \\
\hline 0 & 18 & 21.3 & 0 & 0.0 & 14 & 13.4 & 0 & 0.1 & 14 & 12.8 & 0 & 1.1 \\
\hline 25 & 18 & 18.6 & 0 & 0.0 & 12 & 11.3 & 0 & 0.1 & 0 & 11.5 & 0 & 1.3 \\
\hline 50 & 10 & 15.5 & 0 & 0.02 & 8 & 9.2 & 0 & 0.1 & 11 & 10.2 & 1 & 1.5 \\
\hline 75 & 16 & 12.2 & 0 & 0.1 & 5 & 7.2 & 0 & 0.2 & 8 & 9.2 & 1 & 1.8 \\
\hline 100 & 0 & 9.1 & 0 & 0.3 & 4 & 5.5 & 0 & 0.3 & 0 & 8.2 & 0 & 2.1 \\
\hline 120 & 4 & 6.6 & 0 & 0.8 & 3 & 4.3 & 0 & 0.5 & 8 & 7.4 & 2 & 2.4 \\
\hline 150 & 6 & 4.1 & 2 & 1.4 & 3 & 2.8 & 0 & 0.7 & 5 & 6.3 & 3 & 2.7 \\
\hline 180 & 2 & 2.4 & 3 & 5.9 & 1 & 1.7 & 2 & 1.0 & 5 & 5.2 & 0 & 3.6 \\
\hline 200 & 0 & 1.3 & 7 & 10.3 & 1 & 1.1 & 3 & 1.5 & 4 & 4.5 & 0 & 4.2 \\
\hline 210 & 2 & 1.1 & 14 & 13.0 & 0 & 0.9 & 2 & 1.8 & 5 & 4.2 & 0 & 4.4 \\
\hline 220 & 1 & 0.6 & 15 & 15.9 & 0 & 0.7 & 0 & 2.2 & 0 & 3.8 & 6 & 4.8 \\
\hline 243 & 0 & 0.4 & 22 & 21.4 & 0 & 0.5 & 3 & 2.8 & 3 & 3.3 & 6 & 5.4 \\
\hline 270 & 1 & 0.1 & 22 & 24.9 & 0 & 0.2 & 5 & 4.4 & 3 & 2.5 & 6 & 6.7 \\
\hline 320 & 1 & 0.0 & 10 & 11.9 & 0 & 0.1 & 9 & 8.5 & 2 & 1.5 & 8 & 9.3 \\
\hline 340 & 1 & 0.0 & 5 & 5.6 & 0 & 0.0 & 10 & 11.2 & 1 & 1.1 & 13 & 11.3 \\
\hline 360 & 0 & 0.0 & 0 & 2.0 & 0 & 0.0 & 0 & 14.0 & 0 & 0.9 & 0 & 12.0 \\
\hline 375 & 0 & 0.0 & 1 & 0.7 & 0 & 0.0 & 14 & 16.3 & 0 & 0.7 & 0 & 13.2 \\
\hline 380 & 0 & 0.0 & 1 & 0.5 & 0 & 0.0 & 14 & 17.1 & 0 & 0.7 & 0 & 13.8 \\
\hline 400 & 0 & 0.0 & 0 & 0.1 & 0 & 0.0 & 23 & 20.1 & 1 & 0.4 & 16 & 15.4 \\
\hline 420 & 0 & 0.0 & 0 & 0.0 & 0 & 0.0 & 23 & 22.8 & 0 & 0.3 & 0 & 17.2 \\
\hline 446 & 0 & 0.0 & 0 & 0.0 & 0 & 0.0 & 23 & 24.6 & 0 & 0.3 & 20 & 19.1 \\
\hline $\mathrm{R}_{\mathrm{N}, \mathrm{U}}{ }^{\dagger}$ & - & 0.988 & - & 0.996 & - & 0.875 & - & 0.991 & - & 0.982 & - & 0.952 \\
\hline$S_{H} \ddagger$ & - & 44 & - & 17 & - & 14 & - & 32 & - & 56 & - & 59 \\
\hline
\end{tabular}

$\dagger R_{N, U}$ : Correlation coefficient of the regression line $\ln H$ versus $U\left(N_{o b s}\right)$. See equation (2).

$\mp \mathrm{S}_{\mathrm{H}}$ : Standard deviation on Hcal. in $\mathrm{m}$. See equation (3).

Table 5. Quantiative analysis of section VÁ1, Vágar. The table shows the number of observed and calculated amygdales containing the index mineral per 25 amygdales

\begin{tabular}{|c|c|c|c|c|c|c|c|c|c|c|}
\hline \multirow{2}{*}{$\begin{array}{l}\text { Altitude } \\
\text { metres }\end{array}$} & \multicolumn{2}{|c|}{$\mathrm{Ch}$} & \multicolumn{2}{|c|}{ Th } & \multicolumn{2}{|c|}{$\mathrm{Me}$} & \multicolumn{2}{|c|}{$\mathrm{He}$} & \multicolumn{2}{|c|}{ St } \\
\hline & $\mathrm{N}_{\text {obs }}$ & $\mathrm{N}_{\mathrm{cal}}$ & $N_{\text {obs }}$ & $\mathrm{N}_{\mathrm{cal}}$ & $\mathrm{N}_{\text {obs }}$ & $\mathrm{N}_{\mathrm{cal}}$ & $\mathrm{N}_{\text {obs }}$ & $\mathrm{N}_{\mathrm{cal}}$ & $N_{\text {obs }}$ & $\mathrm{N}_{\mathrm{cal}}$ \\
\hline 10 & 0 & 0.2 & 0 & 0.8 & 0 & 0.0 & 4 & 3.7 & 3 & 3.7 \\
\hline 100 & 0 & 0.3 & 0 & 1.7 & 0 & 0.1 & 9 & 11.3 & 15 & 14.3 \\
\hline 200 & 0 & 0.6 & 0 & 3.9 & 0 & 0.3 & 24 & 22.7 & 21 & 25.0 \\
\hline 235 & 0 & 0.7 & 3 & 3.9 & 0 & 0.4 & 23 & 24.8 & 0 & 23.2 \\
\hline 340 & 0 & 1.2 & 13 & 10.1 & 0 & 1.9 & 15 & 17.7 & 7 & 6.7 \\
\hline 350 & 0 & 1.2 & 9 & 10.7 & 1 & 2.2 & 18 & 16.3 & 5 & 5.4 \\
\hline 380 & 2 & 1.4 & 15 & 12.6 & 3 & 3.1 & 10 & 11.9 & 0 & 2.6 \\
\hline 410 & 2 & 1.7 & 0 & 14.8 & 6 & 4.5 & 7 & 7.9 & 0 & 1.1 \\
\hline 460 & 3 & 2.2 & 19 & 18.4 & 7 & 7.6 & 3 & 3.1 & 0 & 0.2 \\
\hline 475 & 3 & 2.4 & 18 & 19.4 & 9 & 8.8 & 2 & 2.2 & 0 & 0.1 \\
\hline 500 & 6 & 2.7 & 19 & 21.1 & 10 & 11.0 & 1 & 1.2 & 0 & 0.0 \\
\hline 550 & 3 & 3.5 & 21 & 23.8 & 0 & 16.1 & 0 & 0.2 & 0 & 0.0 \\
\hline 610 & 5 & 4.8 & 0 & 25.0 & 24 & 22.0 & 0 & 0.0 & 0 & 0.0 \\
\hline 630 & 6 & 5.3 & 23 & 24.8 & 0 & 23.5 & 0 & 0.0 & 0 & 0.0 \\
\hline $\mathrm{R}_{N, U}{ }^{\dagger}$ & - & 0.987 & - & 0.972 & _ & 0.851 & _- & 0.837 & _ & 0.871 \\
\hline $\mathrm{S}_{\mathrm{H}}^{\ddagger}$ & - & 58 & - & 27 & - & 25 & - & 26 & - & 97 \\
\hline
\end{tabular}

${ }^{\dagger} R_{N}$ : Correlation coefficient of the regression line $\ln H$ versus $U\left(N_{o b s}\right)$. See equation (2).

$\mp \mathrm{S}_{\mathrm{H}}$ : Standard deviation on Hcal. in $\mathrm{m}$. See equation (3). 

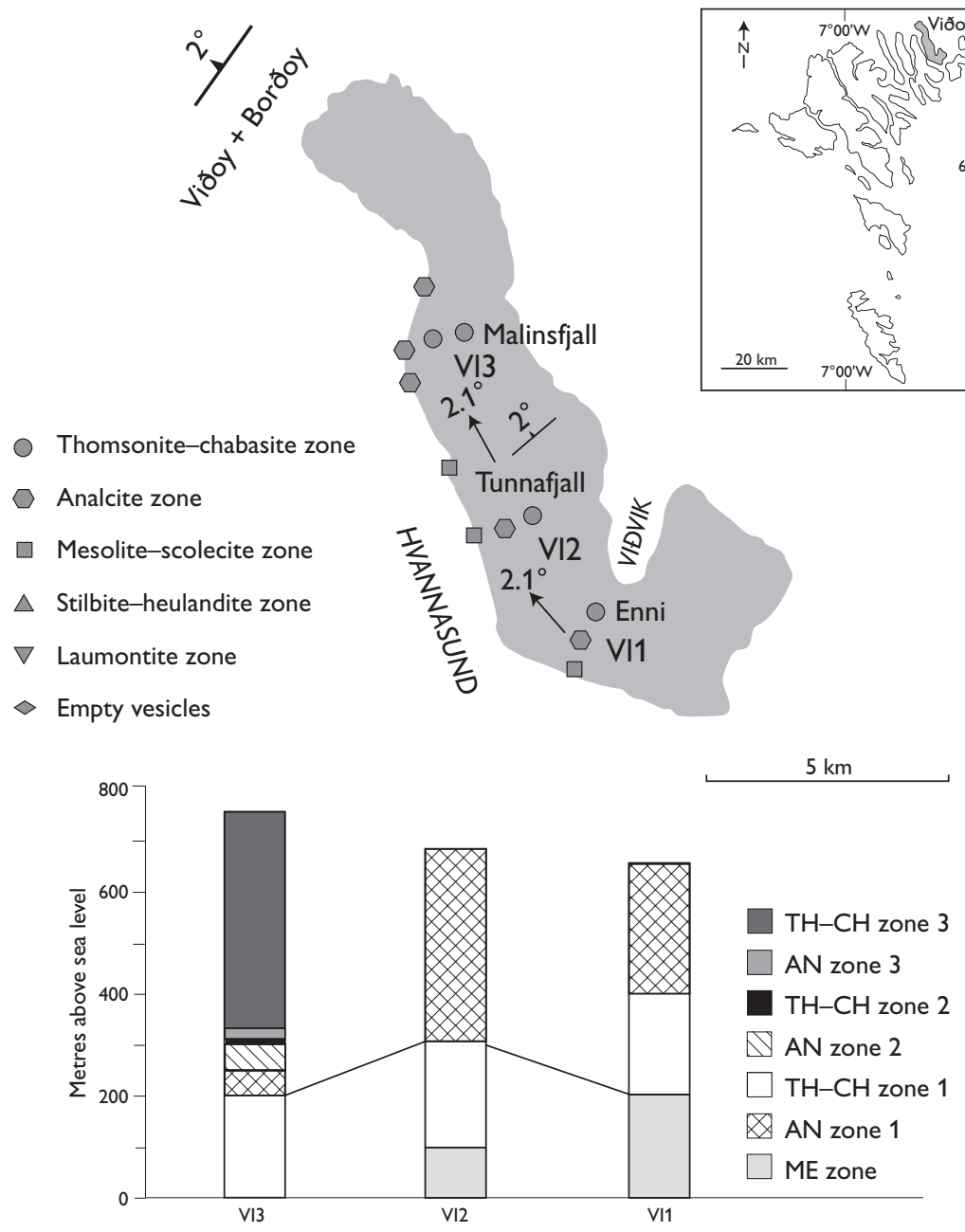

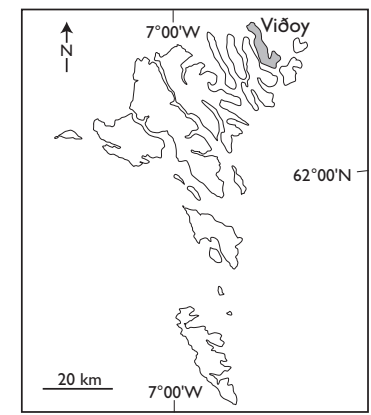

Fig. 11. Distribution of zeolite zones on Viðoy and on sections VI1, VI2 and VI3. The dip and strike of the zeolite zones is indicated on the map. The arrows indicate the strike of the zeolite zones in the profiles. The common dip and strike of the zeolite zones on Borðoy and Viðoy is shown in the upper left corner. that the area has been affected by several generations of mineralisation.

The zoning becomes distinct farther eastwards on sections $\mathrm{BO} 2$ and $\mathrm{BO} 3$. The exposed part of the mesolite zone is $500 \mathrm{~m}$ on $\mathrm{BO} 1$, but $300 \mathrm{~m}$ on $\mathrm{BO} 2$ and $150 \mathrm{~m}$ on BO3 (Fig.10). The analcite and thomsonite-chabazite zones also appear at higher levels on sections $\mathrm{BO} 2$ and BO3. The mineral zones have apparent dips of about $1^{\circ}$ towards the north and east. The analcite zone is about the same thickness on both $\mathrm{BO} 2$ and $\mathrm{BO} 3$, which suggests that the vertical displacement of the two zones reflects differences in altitude of the palaeosurface of the basalt plateau. The lava flows of Borðoy dip 1.6 $6^{\circ}$ to the SE, which means that the zeolite zones are discordant to the lava bedding.

\section{Viðoy (Fig.11)}

The distribution pattern of the secondary minerals on Viðoy is a continuation of that on Borðoy. The mineral zones are displaced downwards compared to those of Borðoy with the result that only between $100 \mathrm{~m}$ and 200 $\mathrm{m}$ of the mesolite zone is exposed on sections VI1 and VI2. On section VI3 a lower analcite zone about $200 \mathrm{~m}$ thick is exposed, which is separated from the thomsonitechabazite zone by about $130 \mathrm{~m}$ of repetitive zoning. The chabazite-thomsonite zone is about $430 \mathrm{~m}$ thick, which is the maximum thickness recorded for that zone within the basalts exposed on the Faroe Islands.

\section{Quantitative analysis of mineral distributions}

Once the position and temperatures are known of the boundaries of the zeolite zones, the geothermal gradient 
and the altitude of the palaeosurface of the basalt plateau can be estimated using least squares regression, assuming a linear palaeotemperature gradient. However, in order to make a reliable estimate, the regression must be based on three or more zone boundaries. This requirement is fulfilled only where the Lopra-1/1A and SU1 sections can be combined. Elsewhere, the number of exposed zone boundaries is too small to calculate a geothermal gradient. In order to overcome this limitation, an attempt has been made to estimate the position of unexposed mineral boundaries from a detailed analysis of the distribution of the exposed mineral zones.

Quantitative analyses carried out on the mineral assemblages of the Lopra-1/1A and Vestmanna-1 boreholes showed that the relative vertical frequency of the minerals followed a skewed distribution with one or more maxima (Jørgensen 1984). This observation has been used to extrapolate non exposed zone boundaries on section VÁ1 on Vágar and SA3 on Sandoy. The two sections were chosen because they are through the middle and the upper basalt formations respectively, the distribution of minerals in them is simple and nearly all rocks sampled contain a large number of well developed amygdales. In order to examine the relationship between the thickness of the zeolite zones and the distribution of index minerals, the number of amygdales containing a particular index mineral was recorded for 25 amygdales (see below). To ensure that the amygdales were selected randomly, all amygdales in the samples from each locality were numbered and the 25 amygdales for examination were selected by using a computerised random number generator. After the amygdales had been chosen, the first formed index mineral was determined and the total number of amygdales containing the same index mineral was recorded. These results are presented as columns $\mathrm{N}_{\text {obs }}$ in Tables 4 and 5 .

Trials were carried out using different exponential distribution functions to find the best correlation between altitude and number of amygdales containing the same index minerals. The experiments showed that the best fit between the observed distribution and the calculated distribution was obtained by the log normal distribution function:

$$
\mathrm{N}_{\mathrm{i}, \mathrm{cal}}=\mathrm{N}_{0} \exp \left(-1 / 2\left[\left(\ln \mathrm{H}-\ln \mathrm{H}_{0}\right) / \mathrm{a}\right]^{2}\right)
$$

where:

$\mathrm{N}_{\mathrm{i}, \text { cal }}$ is the calculated number of amygdales containing index mineral i.

$\mathrm{N}_{0}$ is the total number of amygdales investigated; in this case $\mathrm{N}_{0}=25$.

$\mathrm{H}$ is the altitude of the sample above sea level.
$\mathrm{H}_{0}$ is the altitude where the distribution function attains its maximum value.

$\mathrm{a}$ is a constant.

By transforming equation (1) to a linear form and replacing $\mathrm{N}_{\mathrm{i}, \text { al }}$ by $\mathrm{N}_{\mathrm{i}, \mathrm{bbs}}$, we obtain:

$\ln \mathrm{H}=\mathrm{aU}+\ln \mathrm{H}_{0}$, where $\mathrm{U}= \pm\left[2\left(\ln \mathrm{N}_{0}-\ln \mathrm{N}_{\mathrm{i}, \mathrm{obs}}\right)\right]^{1 / 2}$

The constants a and $\mathrm{H}_{0}$ can be determined by linear regression on $\mathrm{U}$ and $\ln \mathrm{H}$. The calculated number of amygdales $\left(\mathrm{N}_{\mathrm{i}, \text { cal }}\right)$ containing index mineral $\mathrm{i}$ is shown in Tables 4 and 5 . A t-test shows that $\mathrm{U}$ and $\ln \mathrm{H}$ fit a straight line at the $1 \%$ confidence level.

The distribution curves in Figs 12 and 13 give only a best estimate for the height above sea level of the zone boundaries. To assess the degree of uncertainty of these estimates (see below) we calculate the standard deviation of the altitude $(\mathrm{H})$ defined as:

$$
S_{H}=\left[1 /(\mathrm{n}-2) S\left(\mathrm{H}-\mathrm{H}_{\mathrm{c}}\right)^{2}\right]^{1 / 2}
$$

where:

$\mathrm{n}$ is number of pairs $\left(\mathrm{H}, \mathrm{N}_{\mathrm{i}}\right)$ along the distribution curve.

$\mathrm{H}$ is the altitude of the sample above sea level.

$\mathrm{H}_{\mathrm{c}}$ is the calculated altitude of a point on the distribution curves corresponding to $\mathrm{N}_{\mathrm{i}}$ amygdales that contain index mineral $\mathrm{i}$.

In equation (3), $\mathrm{n}$ is reduced by 2 because of the loss of two degrees of freedom by the least squares estimation of a and $\mathrm{H}_{0}$ in equation (1) (Miller \& Freund 1977).

When $\mathrm{N}_{\mathrm{i}}, \mathrm{H}_{0}$ and a are known, $\mathrm{H}_{\mathrm{c}}$ can be calculated from equation (1). $S_{\mathrm{H}}$ for the distribution curves is shown in Tables 4 and 5 and a graphic representation of the calculated distributions of chabazite, thomsonite, mesolite, analcite, heulandite and stilbite on sections SA3 and VÁ1 is shown in Figs 12 and 13. The shape of the curves suggests that a temperature range existed around the altitude $\mathrm{H}_{0}$ in which conditions were favourable for the formation of a particular zeolite. Where $\mathrm{H}<\mathrm{H}_{0}$, palaeotemperatures decreased away from $\mathrm{H}_{0}$ to where they became too low for the zeolite to form. Where $\mathrm{H}>\mathrm{H}_{0}$, palaeotemperatures increased away from $\mathrm{H}_{0}$. The zeolite that was most stable at $\mathrm{H}_{0}$ would have been formed in some interval below $\mathrm{H}_{0}$ but, at higher temperatures, formation of the first zeolite would gradually be inhibited and another one would have become stable. So a zeolite will most likely be found between the maximum slopes of its distribution curve versus height, which corresponds to a palaeotemperature interval. 

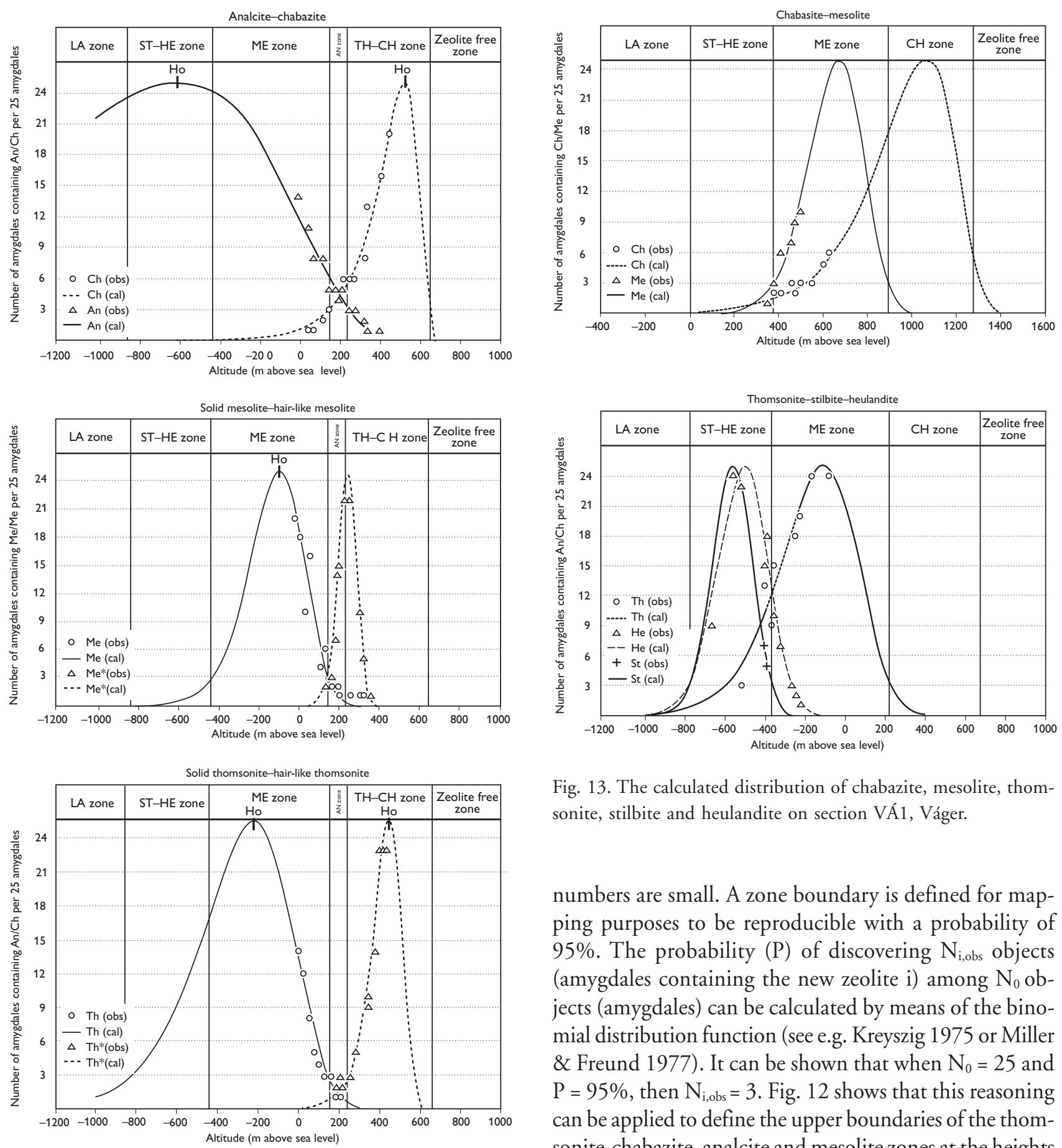

Fig. 13. The calculated distribution of chabazite, mesolite, thomsonite, stilbite and heulandite on section VÁ1, Váger.

numbers are small. A zone boundary is defined for mapping purposes to be reproducible with a probability of $95 \%$. The probability $(\mathrm{P})$ of discovering $\mathrm{N}_{\mathrm{i}, \text { obs }}$ objects (amygdales containing the new zeolite i) among $\mathrm{N}_{0}$ objects (amygdales) can be calculated by means of the binomial distribution function (see e.g. Kreyszig 1975 or Miller $\&$ Freund 1977). It can be shown that when $\mathrm{N}_{0}=25$ and $\mathrm{P}=95 \%$, then $\mathrm{N}_{\mathrm{i}, \mathrm{obs}}=3$. Fig. 12 shows that this reasoning can be applied to define the upper boundaries of the thomsonite-chabazite, analcite and mesolite zones at the heights where the upper end of the appropriate distribution curve intersects the line $\mathrm{N}_{\mathrm{i}}=3$. However, this method cannot be used on the upper boundaries of the stilbite-heulandite and laumontite zones, because stilbite, heulandite and laumontite do not exist as first formed index minerals in section SA3. Fig. 12 shows that solid mesolite occurs most commonly in the mesolite zone and thomsonite occurs most commonly in the stilbite-heulandite plus the mesolite zone. If we assume that $95 \%$ of the two index minerals occurs within the zones in question, we can define the 
Table 6. Estimated palaeothermal gradients and the altitude of the palaeosurfaces at Lopra-1/1A and sections SU1, VÁ1 and SA3

\begin{tabular}{lcccccccc}
\hline Zeolite zone & $\begin{array}{c}\text { Zeolite } \\
\text { free }\end{array}$ & Ch-Th & Me & St-He & La & $\begin{array}{c}\text { Palaeothermal } \\
\text { gradient }\end{array}$ & $\begin{array}{c}\text { Altitude of } \\
\text { palaeosurface }\end{array}$ & $\begin{array}{c}\text { Correlation } \\
\text { coefficient }\end{array}$ \\
\hline $\begin{array}{l}\text { Temperatures at } \\
\text { the zone boundaries }\end{array}$ & $40-$ & $50-$ & $90-$ & $110-$ & $190-$ & & m above sea \\
\hline
\end{tabular}

Altitude of zone boundaries

( $m$ above sea level):

$\begin{array}{lrrrrrrrr}\text { Lopra-1/1A + SU1 } & - & - & -590 & -1200 & -2200 & 66 \pm 9 & 443-983 & 0.9547 \\ \text { VÁ1 } & 1325 & 900 & 380 & - & - & 63 \pm 8 & 1760-2080 & 0.9181 \\ \text { SA3 } & 653 & 150 & -425 & -825 & - & 56 \pm 7 & 1150-1524 & 0.8689\end{array}$

heights of the lower boundaries of the mesolite and the stilbite-heulandite zones where the lower end of the distribution curves interest the line $\mathrm{N}_{\mathrm{i}}=3$. That $95 \%$ of an index mineral occurs within the interval in question can be verified by plotting the accumulated distribution of the index mineral in a probability diagram.

Analcite occurs only sporadically below $340 \mathrm{~m}$ on section VÁ1 (Fig. 13), so the analcite zone cannot be defined on this profile. The other zone boundaries were calculated as described above.

\section{Estimation of palaeothermal gradients and altitudes of palaeosurfaces}

If we assume that the palaeothermal gradient was constant with depth, it may be estimated by linear regression on the data from the combined Lopra-1/1A plus SU1 sections, the mineral zone boundaries obtained by calculation and shown in Figs 12 and 13 and the temperatures shown in Fig. 2. The resulting estimates are shown in Table 6. The new estimate from southern Suðuroy is consid- ered more accurate than that in Jørgensen (1984), which was based on the mineral distribution in the Lopra- 1 borehole only. From these palaeogeothermal gradients and assuming a surface temperature of $7^{\circ} \mathrm{C}$, the altitudes of the palaeosurface of the basalts has been estimated (Table 6).

The altitude differences between the estimated palaeosurface and stratigraphic marker horizons $\mathrm{A}$ and $\mathrm{C}$ is different at the three localities (Table 7). On southern SuJuroy, the palaeosurface was about $0.7 \mathrm{~km}( \pm 0.3 \mathrm{~km})$ above present day sea level, i.e. close to the extrapolated top of the lower basalt formation. On Vágar, the palaeosurface was $1.9 \pm 0.2 \mathrm{~km}$ above the extrapolated top of the lower basalt formation (or $0.5 \pm 0.2 \mathrm{~km}$ above the top of the middle formation), while on Sandoy, the palaeosurface was $1.7 \pm 0.2 \mathrm{~km}$ above the top of the middle basalt formation. This suggests that the focus of volcanism shifted laterally with time as will be discussed below.

Table 7. Estimated thicknesses of the basalt formations along various sections across the Faroe Islands

\begin{tabular}{|c|c|c|c|c|c|c|}
\hline Area & Section & Formation & $\begin{array}{c}\text { Altitude of } \\
\text { palaeo surface } \\
\text { in } \mathrm{m} \text { above sea } \\
\text { level (Table 6) }\end{array}$ & $\begin{array}{c}\text { Present } \\
\text { stratigraphic } \\
\text { thickness in } m\end{array}$ & $\begin{array}{c}\text { Local altitude } \\
(\mathrm{m}) \text { of }\end{array}$ & $\begin{array}{l}\text { Altitude of } \\
\text { palaeosurface } \\
\text { in } \mathrm{m} \text { above } \\
\text { A- or C-horizon }\end{array}$ \\
\hline S. Suðuroy & Lopra-1/1A + SU1 & L. Formation & $443-983$ & $>3100^{1}$ & A-horizon: 700 & A-horizon: $\quad-257-283$ \\
\hline W. Vágar & VÁ1 & M. Formation & $1760-2080$ & $1410^{2}$ & A-horizon: $\quad 60$ & A-horizon: 1700-2020 \\
\hline E. Sandoy & SA3 & U. Formation & $1150-1525$ & $700-900^{1,3}$ & C-horizon: -400 & C-horizon: 1550-1924 \\
\hline
\end{tabular}

Sources: 1) Larsen et al. 1999, 2) Waagstein \& Hald 1984, 3) Waagstein 1988. 


\section{Discussion}

\section{Palaeothermometry and zone boundaries}

The use of zeolites as palaeotemperature indicators is based on the assumptions: (1) that the zeolite zones reflect univariant equilibrium with a high coefficient $\mathrm{dP} / \mathrm{dT}$ of the Clausius-Clapeyron equation and: (2) that the formation temperature of the minerals is independent of the chemical composition of the hydrothermal solution.

Assumption (1) is fulfilled because the properties of condensed systems are nearly independent of pressure, if the pressure is not extremely high and the temperature is below the supercritical temperature $\left(374^{\circ} \mathrm{C}\right)$ of water. We can also estimate the error of the temperature determination when we ignore the external pressure of the system. The coefficient $\mathrm{dP} / \mathrm{dT}$ is known only for a small number of systems that involve zeolites, but experimental studies of the systems stilbite-laumontite- $\mathrm{H}_{2} \mathrm{O}$ and laumontitewairakite- $\mathrm{H}_{2} \mathrm{O}$ show that $\mathrm{dP} / \mathrm{dT}$ is of the order of $25-33$ bars/degree in the range $P_{\text {fluid }}=0-2000$ bars (Liou 1971; Jové \& Hacker 1997). Consequently, if the external pressure is equal to the fluid pressure and the original thickness of the lava pile is $2 \mathrm{~km}$, the likely maximum error of the temperature determination is $8^{\circ} \mathrm{C}$, disregarding the depth between the boundary of the zeolite zone and the unknown altitude of the palaeosurface.

In contrast to the effect of pressure, the chemical composition of the rock and the hydrothermal fluids has a much larger effect on the formation temperature of the minerals. Barth-Wirsching \& Höller (1989) studied the formation of zeolites in glasses of different chemical compositions. They found that replacing rhyolitic glass by basaltic glass caused the formation temperature of different zeolites to increase by between $50^{\circ} \mathrm{C}$ and $100^{\circ} \mathrm{C}$. This demonstrates the importance of choosing a reference area for the thermometry that consists of rocks with a chemical composition similar to that of the rocks in the area studied.

Other factors may also affect the formation of zeolites such as the texture of the rock, the content of glass and the porosity of the rock (Gottardi 1989).

The geothermal areas on Iceland were used as a reference for the thermometry in the present study. The basalts from the Faroe Islands are all tholeiites, but show large compositional variations that range from picritic to ferrobasaltic (Waagstein 1988). Most of the Icelandic basalts are also tholeiites, but minor amounts of acid rocks (rhyolites, andesites, granophyres, acid tuff) are found, mainly associated with volcanic centres (Sigurdsson 1967). This compositional variation of the Icelandic rocks may partly explain the large variation in temperature at the boundaries of the zeolite zones mentioned above (Fig. 2).

From the description of the sections shown in Figs 12 and 13 (and listed in Appendix A), it can be seen that the distribution of index minerals varies gradually between successive zeolite zones. An index mineral that defines a zone may thus overlap the boundaries of neighbouring zones which makes it difficult to define the exact boundaries between mineral zones. The problem was solved by statistical analysis on sections SA3 and VÁ1 from which the boundaries of the zeolite zones could be defined as the locations where 3 out of 25 amygdales contain the appropriate index mineral.

The overlap problem occurs in all the sections described in Appendix A and, because of the lack of quantitative mineral data, the distributions in SA3 and VÁ1 were the only ones that could be described by a simple distribution model. On all other sections, the zone division was based on a crude estimate of the abundance of the index minerals around the zone boundaries. Figs 12 and 13 show that the overlap between the zeolite zones varies from $100 \mathrm{~m}$ to $300 \mathrm{~m}$. which means that, in the worst case, the zone boundaries could be determined with an accuracy of only $\pm 150 \mathrm{~m}$ when the zone boundary localities are based on a subjective estimate of the abundance of index minerals.

\section{Volcanic and tectonic evolution}

The average of the three calculated palaeogeothermal gradients is about $60^{\circ} \mathrm{C} / \mathrm{km}$ and there may be a small decrease in the gradient from the lower to the upper basalt formation. If real, this decrease could reflect either a reduction in heat flow with time or a variation in heat flow with locality.

Rasmussen \& Noe-Nygaard's $(1969,1970)$ summary of the volcanic evolution of the Faroe Islands that volcanic activity started in the west and moved eastwards with the times, must be modified, because evidence from the Lopra-1 drillhole indicates that the lavas of the lower formation were erupted from local centres (Waagstein 1988) and not from centres situated west of the present islands. This change might explain the change in the palaeogeothermal gradients shown in Table 6 . The eruption centres of the lower and middle formations were located in the Faroe Islands and the geothermal gradient was high. Movement away to the east during eruption of the upper formation led to a decrease in the gradient. 


\section{Regional distribution of the zeolite zones}

At the time when the Faroe lava pile was first mineralised, the thermal gradient seems to have been fairly constant, at least regionally and for some time. This is suggested by the rough equality of the calculated palaeogeothermal gradients from the southern, western and central part of the Faroes that represent different stratigraphic levels (Table 6). The overall regional distribution of zeolites is thus considered to reflect primarily variations in the maximum depth of burial of the basalt rather than differences in heat flow. The inferred palaeosurface on southern Suduroy is close to the extrapolated top of the lower formation (Table 7), indicating that the total thickness of middle and upper formation lavas must have been small in this area. In contrast, in eastern Sandoy about $50 \mathrm{~km}$ farther north where the exposed thickness of the upper formation is of the order of $1 \mathrm{~km}$, the estimated palaeosurface is $>1.5 \mathrm{~km}$ above the base of the upper formation or stratigraphically approximately $3 \mathrm{~km}$ above the lower-middle formation boundary. If we use the palaeogeothermal gradient calculated on Sandoy, then the palaeosurface of the upper formation on Viðoy may have been at about 1.3 $\mathrm{km} \pm 0.2 \mathrm{~km}$ above sea level. These results suggest that the upper formation had a similar or only slightly smaller thickness in the north-eastern part of the Faroes compared with the central part of the islands. On the other hand, the upper formation seems to have been much thinner or non existent in both the western and southern parts of the Faroes (Table 7) and the middle formation must also have been thin in the south.

The inferred thinning of the middle and upper formations from the central to southern part of the Faroes is consistent with a northerly source area for these basalts, centred on the rift between the Faroes and Greenland (Waagstein 1988; Hald \& Waagstein 1991; Larsen et al. 1999). The thinning of the upper formation towards the west is consistent with Rasmussen \& Noe-Nygaard's (1969, 1970) interpretation of an easterly source for this part of lava pile and may suggest a shift in the focus of volcanism.

The first order regional zeolite distribution pattern is affected by local perturbations of the mineral zone boundaries (Fig. 4). These perturbations show up as shifts in the dip of the zone boundaries within and between neighbouring islands as well as shifts in the degree of mineralisation. The latter effect is clearly seen towards the south. Southern Sandoy and northern Suðuroy are heavily mineralised, although at different temperatures, whereas the vesicles of the basalt in the adjoining areas of northern Sandoy and southern Suðuroy usually contain no zeolites.
On the northern and western islands, the zone distribution shows a tendency to symmetry around the narrow NW-SE-trending sounds that separate the islands (Figs 7-9). The distributions on the neighbouring north-eastern islands of Borðoy and Viðoy similarly seem to be mirror imaged, a distribution difficult to explain by variations in depth of burial. It is more likely that the distributions reflect local differences in palaeotemperature, perhaps related to the circulation of water underground with high temperatures in areas of up welling and low temperatures in areas of down welling. The symmetry of the zonal distribution patterns suggests that these temperature anomalies are in part related to NW-SE-trending eruption fissures or zones of weakness separating the present islands (Noe-Nygaard 1968; Rasmussen \& Noe-Nygaard 1969, 1970). They are subparallel to the transfer zones in the Faroe-Shetland Basin described by Rumph et al. (1993) and later authors, and may indicate the presence of similar deep seated features. Both the regional and the local distribution of zeolite assemblages probably reflect the basic volcanic-tectonic systems that led to the development of the Faroe Islands.

\section{Acknowledgements}

I want to express my gratitude to the late Arne Noe- $\mathrm{Ny}$ gaard and Jóannes Rasmussen for discussions and support during the first phase of this project. I also want to express my thanks to the Geological Survey of Denmark and Greenland for financial support to the present project, to curator Ole V. Petersen, Geological Museum, Copenhagen for permission to study the collection of zeolites from the Faroes and to Mrs. Kitty Jørgensen, Næstved, who kindly made her collection of zeolites from the Faroes available for my study. Finally, I want to thank Regin Waagstein, James Chalmers and Kjeld Alstrup for discussions and constructive criticism of the various versions of the manuscript. The comments of two anonymous reviewers are likewise greatly acknowledged.

\section{References}

Barth-Wirsching, U. \& Höller, H. 1989: Experimental studies on zeolite formation conditions. The European Journal of Mineralogy 1, 498-506.

Betz, V. 1981: Zeolites from Iceland and the Faroes. Mineralogical Record 12, 5-26.

Breck, D.W. 1974: Zeolite Molecular Sieves: Structure, Chemistry and Use. New York: John Wiley. 
Brewster D. 1825: A description of Levyne, a new mineral species. Edinburgh Journal of Science 2, 322-334.

Currie, J. 1905: The minerals of the Faroes, arranged topographically. Transactions of the Edinburgh Geological Society (session 1905-1906) 9, 1-68.

Debes, L.J. 1673: Færoæ et Færoa Reserata. Hafniæ: Suptibus Daniels Paaulli Reg. Bibl. (In Latin and Danish).

Görgey, R. 1910: Ein Beitrag zur topographischen Mineralogie der Färöer. Neues Jahrbuch der Mineralogie und Palaeontologie XXIX, 269-315.

Gottardi, G. 1989: The genesis of zeolites. European Journal of Mineralogy 1, 479-487.

Gottardi, G. \& Galli, E. 1985: Natural zeolites. In: Wyllie, P.J., Goresy, A.E., von Engelhard, W. \& Hahn, T. (eds): Minerals and Rocks No. 18. Berlin: Springer Verlag.

Hald, N. \& Waagstein, R. 1991: The dykes and sills of the early Tertiary Faroe Islands basalt plateau. Transactions of the Royal Society of Edinburgh: Earth Sciences 82, 373-388.

Jørgensen, O. 1984: Zeolite zones in the basaltic lavas of the Faroe Islands. Annales Societatis Scientiarum Faroensis. Supplementum 9, 71-91.

Jørgensen, O. 1997: Zeolites and other secondary minerals in cavities and veins, Lopra-1/1A well, Faroe Islands, 1996, 8 pp. + plates. Unpublished Report. Technical studies prepared for Dansk Olie og Gasproduktion A/S 1997 (in archives of the Geological Survey of Denmark and Greenland, GEUS Report file 26129).

Jove, C. \& Hacker, B.R. 1997: Experimental investigation of laumontite ${ }^{\circledR}$ wairakite $+\mathrm{H}_{2} \mathrm{O}$; a model diagenetic reaction. American Mineralogist 82, 781-789.

Kreyszig, E. 1975: Advanced Engineering Mathematics, 707-709, 783-787. New York: John Wiley.

Kristmannsdóttir, H. 1982: Alteration in the IRDP drillhole compared with other drillholes in Iceland. Journal of Geophysical Research 87 (B8), 6525-6531.

Kristmannsdóttir, H. \& Tómasson, J. 1978: Zeolite zones in geothermal areas in Iceland. In: Sand, L.B. \& Mumpton, F.A. (eds): Natural zeolites, occurrence, properties and use, 277-284. Oxford: Pergamon Press.

Larsen, L.M., Waagstein, R., Pedersen, A.K. \& Storey, M. 1999: Trans-Atlantic correlation of Palaeogene volcanic successions in the Faroe Islands and East Greenland. Journal of the Geological Society (London) 156, 1081-1095.
Liou, J.G. 1971: Stilbite-laumontite equilibrium. Contribution to Mineralogy and Petrology 31, 171-177.

Miller, I. \& Freund, J.E. 1977: Probability and statistics for engineers, 50-63. Englewood, New Jersey: Prentice-Hall.

Neuhoff, P.S., Watt, W.S., Brid, D.K. \& Petersen, A.K. 1997: Timing and structural relations of regional zeolite zones in basalts of the East Greenland continental margin. Geology 25, 803-806.

Noe-Nygaard, A. 1968: On extrusion forms in plateau basalts; shield volcanoes of 'scutulum' type. Science in Iceland 1,10-13.

Rasmussen, J. \& Noe-Nygaard, A. 1969: Beskrivelse til geologisk kort over Færøerne i målestok 1:50 000. Danmarks Geologiske Undersøgelse I Række 24, 370 pp. + map vol. (in Danish with summaries in Faroese and English).

Rasmussen, J. \& Noe-Nygaard, A. 1970: Geology of the Faroe Islands (pre-Quaternary). Danmarks Geologiske Undersøgelse I Række 25, 142 pp.

Rumph, B., Reaves, C.M., Orange, V.G. \& Robinson, D.L. 1993: Structuring and transfer zones in the Faroe Basin in a regional tectonic context. In: Parker, J.R. (ed.): Petroleum Geology of Northwest Europe: Proceedings of the 4th Conference, 9991009. London: Geological Society.

Sigurdsson, H. 1967: The Icelandic basalt plateau and the question of SIAL. In: Björnsson, S. (ed.): Iceland and mid-ocean ridges. Societas Scientiarium Islandica XXXVIII, 32-46.

Waagstein, R. 1988: Structure, composition and age of the Faroe basalt plateau. In: Morton, A.C. \& Parson, L.M. (eds): Early Tertiary Volcanism and the Opening of the NE Atlantic. Geological Society (London) Special Publication 29, 225-238.

Waagstein, R. \& Hald, N. 1984: Structure and petrography of a $660 \mathrm{~m}$ lava sequence from the Vestmanna-1 drillhole. In: Berthelsen, O., Noe-Nygaard, A. \& Rasmussen, J. (eds): The Deep Drilling Project 1980-1981 in the Faroe Islands. Føroya Fródskaparfelag, Tórshavn, 39-65.

Walker, G.P.L. 1960: Zeolite zones and dike distribution in relation to the structure of the basalts of Eastern Iceland. Journal of Geology 68, 515-528.

Walker, G.P.L. 1970: The distribution of amygdale minerals in Mull and Morvern (Western Scotland). In: Murty, T.V.V.G.R.K. \& Rao, S. (eds): Studies in Earth Sciences, West Commemoration Volume, 181-194. Faridibad, India: Today \& Tomorrow's Publishers. 
Appendix A: Locations of sites along the sections discussed in the paper and minerals found in vesicles and fractures at each locality. The mineral zones are defined in Fig. 2

\begin{tabular}{|c|c|c|c|c|c|}
\hline Profile & Locality & $\begin{array}{l}\text { Altitude } \\
(\mathrm{m})\end{array}$ & Vesicles & Fractures & Zone \\
\hline SU1 & Road exposure $0.5 \mathrm{~km}$ north of Lopranseiði & 25 & No vesicles. & $\begin{array}{l}\mathrm{He}-\mathrm{Me} . \mathrm{He}-\mathrm{St}-\mathrm{Ch} . \\
\text { An-Ch. Ca. Qz. }\end{array}$ & $2-3$ \\
\hline SU1 & The northern entrance of the Sumba tunnel & 70 & - & $\begin{array}{l}\mathrm{He}-\mathrm{Me} . \mathrm{He}-\mathrm{Ch} . \\
\text { Me-An. Ca. Ch-An. }\end{array}$ & $2-3$ \\
\hline SU1 & Road exposure at the W slope of Siglidalur & 200 & - & Ch-An. Ca. & $1-3$ \\
\hline SU1 & $\begin{array}{l}\text { Road exposure at small stream on the W } \\
\text { slope of Spinarnir }\end{array}$ & 380 & - & Ch-Th*. Op. Qz. & $1-2$ \\
\hline SU1 & & 288 & - & Ch-An. Op. Qz. Ca. & $1-2$ \\
\hline SU1 & Road exposure at Stórá, $1 \mathrm{~km}$ SE of Spinarnir & 340 & - & Th*-An. Op. Qz. Ca. & $1-2$ \\
\hline SU1 & Lambaklettur & 235 & - & As above. & $1-2$ \\
\hline SU2 & Road exposure $3 \mathrm{~km} \mathrm{E}$ of Øravík & 100 & Empty vesicles. & Ca. Qz. & $1-2$ \\
\hline SU2 & Road exposure $2.5 \mathrm{~km}$ E of Øravík & 25 & Ce-An. Ch-Me*-Th*. & An. Ca. St. & $1-2$ \\
\hline SU2 & Exposure in Dalsá, $1.5 \mathrm{~km} \mathrm{~W}$ of Øravík & 100 & An, Me*. Ch. Ca. Cld. & Cld. Qz. & $1-2$ \\
\hline SU2 & $\begin{array}{l}\text { Road exposure just north of Høgiklovningur, } \\
2.5 \mathrm{~km} \mathrm{~S} \text { of Øravik }\end{array}$ & 250 & $\mathrm{Ca}-\mathrm{An} . \mathrm{Ph}-\mathrm{Th}$. & Cld. Me*. & $1-2$ \\
\hline SU2 & Øraskarð & 278 & Empty vesicles. & Ca. & $1-2$ \\
\hline SU2 & NW slope of Nónfjall & 360 & Th*-An-Ch. & Th-Th*-An-Ch. & $1-2$ \\
\hline SU2 & The summit of Nónfjall & 427 & $\mathrm{An}-\mathrm{Me} * \mathrm{Ca} . \mathrm{Qz}$. & An. & $1-2$ \\
\hline SU2 & $\begin{array}{l}\text { Road exposure } 0.8 \mathrm{~km} \mathrm{~S} \text { of the church in } \\
\text { Fámjin }\end{array}$ & 80 & Ac. Ch. & Ch.An. Qz. & $1-2$ \\
\hline SU2 & $\begin{array}{l}\text { Road exposure } 0.5 \mathrm{~km} \mathrm{~S} \text { of the church in } \\
\text { Fámjin }\end{array}$ & 20 & An-Th.Th*-Ch. & An. St. Me*. & $1-2$ \\
\hline SU5 & Høvdatangi, Froðba & $0-25$ & Empty vesicles. & Empty fractures. & - \\
\hline SU5 & Skarvatangi & 60 & $\mathrm{Na}-(\mathrm{Th}, \mathrm{An}) . \mathrm{Me}-\mathrm{Th} . \mathrm{Ch}$. & $\begin{array}{l}\text { Me-Me*. Me-St. } \\
\text { Me-An.St-Ch. St*-St. }\end{array}$ & $2-3$ \\
\hline SU5 & Exposure at the road Froðba-Nakkur & 90 & An-St. Me-St.Th-St.Th-Me. & Me*-Ch. & $2-3$ \\
\hline SU5 & - do - & 130 & Na. Ch. Me-Sc. Me-Ch. Th-Ga-Ch. & $\begin{array}{l}\mathrm{Na}-\mathrm{St} *-\mathrm{St} . \mathrm{An}-\mathrm{Th} \\
\mathrm{St}-\mathrm{Ch} .\end{array}$ & $2-3$ \\
\hline SU5 & - do - & 140 & An-Th*-Ch. & $\begin{array}{l}\text { An-Me. St-Me-St. } \\
\text { Me-La, Ch. }\end{array}$ & $2-3$ \\
\hline SU5 & - do - & 250 & Me-Me*.Th-Me. & An. He-St. Op, Cld, Ca. & $2-3$ \\
\hline SU5 & Summit of Kambur & 483 & $\begin{array}{l}\mathrm{Ce}-\mathrm{He} . \mathrm{Me} \text { in large acicular crystals like } \\
\text { scolecite. }\end{array}$ & Ce-Me*, Ce-An. He. & $2-3$ \\
\hline SU9 & $\begin{array}{l}\text { Hamranes and the southern entrance of the } \\
\text { tunnel Hvalba-Sandvík }\end{array}$ & $0-100$ & $\begin{array}{l}\text { He-St. He-Me-Ch. An-Me. Me-Me*- } \\
\text { Gy. Me-Gy+Ap. }\end{array}$ & $\begin{array}{l}\text { He-St-Ap. Me*-La. } \\
\text { Th-Ch; He-(St, La). } \\
\text { He-Ap. He-La. La-Ca. } \\
\text { La-Gy. }\end{array}$ & $2-3$ \\
\hline SU9 & The southern slope of Skálafjall & 70 & An-He. Me-Th. Cld. & As in the vesicles. & $2-3$ \\
\hline SU9 & - do - & 120 & As above. & & $2-3$ \\
\hline SU9 & - do - & 160 & Scolecite-like Me.An-He. Me-He. & $\mathrm{He}-\mathrm{Me}-\mathrm{Me}$ *. Ca. & $2-3$ \\
\hline SU9 & - do - & 200 & As above. & & $2-3$ \\
\hline SU9 & - do - & 240 & Me-St. He-St. He-Ch. & $\mathrm{Ca}-(\mathrm{Ch}, \mathrm{Le})$. & $2-3$ \\
\hline SU9 & - do - & 260 & Me-Me*-Ch.Th-Ch. & & $2-3$ \\
\hline
\end{tabular}




\begin{tabular}{|c|c|c|c|c|c|}
\hline Profile & Locality & $\begin{array}{l}\text { Altitude } \\
(\mathrm{m})\end{array}$ & Vesicles & Fractures & Zone \\
\hline SU9 & The southern slope of Skálafjall & 290 & Th*-Ch. Me-Me*-Ch. Ca. & & $1-3$ \\
\hline SU9 & The summit of Skálafjall & 374 & As above. & & $1-3$ \\
\hline SA1 & $\begin{array}{l}\text { Exposure at the cost line and at road } \\
\text { cuttings in Søltuvík }\end{array}$ & $0-50$ & Many empty vesicles. He. St. La. Ca. & $\begin{array}{l}\text { La-St-Ca. Mo-He-St. } \\
\text { Ca. }\end{array}$ & $2-4$ \\
\hline SA1 & $\begin{array}{l}\text { Road exposure at the road Sandur-Søltuvík, } \\
1.5 \mathrm{~km} \text { west of Sandur }\end{array}$ & 60 & $\mathrm{He}-\mathrm{St}$. He+Me-St.Th-St. & $\mathrm{He}+\mathrm{Me}-\mathrm{St} . \mathrm{Ca}$. & $2-4$ \\
\hline SA1 & $\begin{array}{l}\text { Large quarry at lake Sandvatn, } 1 \mathrm{~km} \text { north } \\
\text { of Sandur }\end{array}$ & 10 & No vesicles. & St-La-Ca. He. St. & $2-4$ \\
\hline SA1 & Sprutthol, Sandsvágur Bay & 30 & He-Me. Ch. Ca. & St. Ca. & $2-4$ \\
\hline SA3 & Húsavíklið $\mathrm{N}$ of Húsavík & $0-75$ & $\mathrm{He}-\mathrm{Me} . \mathrm{Ce}-\mathrm{Me} . \mathrm{Th}-\mathrm{Me}$. & St. & $2-3$ \\
\hline SA3 & Road exposure $2 \mathrm{~km} \mathrm{~W}$ of Skálavík & 78 & Me-Ch. Gi. Cld. & $\mathrm{He}-\mathrm{St}-\mathrm{Ca}$. & $2-3$ \\
\hline SA3 & Road exposure at Hálsur, $3 \mathrm{~km} \mathrm{~W}$ of Skálavík & 119 & Me-Th. Me-Me*. He-Th. & St-St*.Ap. & $2-3$ \\
\hline SA3 & Urðarklettar NW of Húsavík & 120 & Me-Th-Ch.An-Me-Th. & & $2-3$ \\
\hline SA3 & Húsavíklið $\mathrm{N}$ of Húsavík & 150 & Me-Th-Me.An. He. Ca. & & $2-3$ \\
\hline SA3 & Exposure at Gravaráin & 140 & Me-Th. He-St. He-Ch.An. & St. La. & $2-3$ \\
\hline SA3 & Urðatklettar, NW of Húsavík & 150 & $\mathrm{Ce}-\mathrm{Me}-\mathrm{Th}-\mathrm{Me}$, Me-Me*-Gy. & Me*. & $2-3$ \\
\hline SA3 & - do - & 180 & $\mathrm{Ca}-\mathrm{Me}-\mathrm{Me}$ *.An-Me. & & $2-3$ \\
\hline SA3 & Húsavíklið, $\mathrm{N}$ of Húsavík & $180-200$ & Me-Th*.An-Th-Me*. & & $2-3$ \\
\hline SA3 & Exposure at Gravaráin & $210-220$ & Me-Ca-.Me*.An-Me*.An-Th*. & $\mathrm{Ca}-\mathrm{He}-\mathrm{St} . \mathrm{Ca}-\mathrm{Ap}$. & $1-2$ \\
\hline SA3 & Exposure at Stórá & 243 & Me-Me*.Me-Th*-Ca. Gi. & $\mathrm{Ca}-\mathrm{St}$. & $1-2$ \\
\hline SA3 & Summit of Heiðafjall & 266 & He-Me*.An-Me*-An.Th*. & & $1-2$ \\
\hline SA3 & Exposure at Stórá & $320-340$ & Me-An-Me*. Ch.Th*. & & $1-2$ \\
\hline SA3 & Skriðubakki & $360-380$ & Th*-Ch. Me*-Ch. & Me*. & $1-2$ \\
\hline SA3 & - do - & $400-420$ & $\begin{array}{l}\mathrm{Ch}-\mathrm{Th} * \text {.Th*-Ch.An. Many empty } \\
\text { vesicles. }\end{array}$ & & $0-1$ \\
\hline SA3 & The summit of Pætursfjæll & 447 & Ch-Th*. Many empty vesicles. & & $0-1$ \\
\hline SA5 & Dalsnípa & 150 & $\begin{array}{l}\text { Me-An. Me-Ap-St.Th-Ap. Ch-Ap. } \\
\text { Th-Ch.An-Ch. }\end{array}$ & Le. He-St-Ap. Cld. & $2-3$ \\
\hline SA5 & $\begin{array}{l}\text { The S slope of Skúvoyafjall, } 0.6 \mathrm{~km} \mathrm{NW} \text { of } \\
\text { Dalsnipa }\end{array}$ & 280 & Me-St, Me-An, He. & & $2-3$ \\
\hline SA5 & The summit of Skúvoyafjall & 354 & Ce-Ch. Ce-Th-Th*. & St. & $1-3$ \\
\hline SA5 & $\begin{array}{l}\text { Road exposure at the end of the road } \\
\text { Dalur-Skuvoyafjall }\end{array}$ & 308 & $\mathrm{He}-\mathrm{Me} . \mathrm{Th}-\mathrm{Me} \mathrm{e}^{*} \mathrm{Ch}-\mathrm{Th}$ *. & & $1-3$ \\
\hline SA5 & Road exposure $2 \mathrm{~km} \mathrm{SW}$ of Dalur & 260 & Th-Ap. St-Me-Le.Th-Le. & He-Me-La. & $2-3$ \\
\hline SA5 & Dalur harbour & $0-30$ & Ch. Ch-Le.An-Th-Th*. He-Me-St. & $\begin{array}{l}\text { Ch. Le. Me-Ap-St. } \\
\text { Me-Me*. }\end{array}$ & $2-3$ \\
\hline SA5 & Road exposure at Kinnartangi & 100 & Ch. Ch-Th-Ch. St-Me-Gy. Gy-Me. & & $2-3$ \\
\hline SA5 & The SE slope of Stórafjall & 160 & Ch.An-Me-Me*. St-Th. & Ch. St. He. Gy. & $2-3$ \\
\hline SA5 & - do - & 220 & Me-Me*-Ch.Th-Me. & & $2-3$ \\
\hline SA5 & - do - & 260 & As above. & & $2-3$ \\
\hline SA5 & - do - & 300 & Ph. Gi-Me*.Th*-Le. Me-Me*. & & $1-2$ \\
\hline SA5 & - do - & 340 & As above. & Ch-Le. He-Me-St-Ap. & $1-2$ \\
\hline SA5 & - do - & 360 & As above. & He-Le. & $1-2$ \\
\hline
\end{tabular}




\begin{tabular}{|c|c|c|c|c|c|}
\hline Profile & Locality & $\begin{array}{l}\text { Altitude } \\
(\mathrm{m})\end{array}$ & Vesicles & Fractures & Zone \\
\hline SA5 & The summit of Stórafjall & 396 & $\mathrm{Ch}+\mathrm{Ph} . \mathrm{Gi}-\mathrm{Me}$. Me*-Ch. Th-Ch. & & $1-2$ \\
\hline SA5 & The NE slope of Stórafjall & 310 & Ch. Me*-Ch. He. & & $1-2$ \\
\hline SA5 & $\begin{array}{l}\text { Trigonometric station on the NE slope of } \\
\text { Stórafjall }\end{array}$ & 217 & Ch. An. Me-Ch. He-St. He-Me-Gy. & & $2-3$ \\
\hline SA5 & Road exposure at Tjarnaheyggjur & 60 & As above. & Me-Ca. & $2-3$ \\
\hline VÁ1 & Reyðastiggajatangi & $0-10$ & $\mathrm{He}-\mathrm{St}, \mathrm{An}$. & Cl-St-Ca-La. & $3-4$ \\
\hline VÁ1 & $\begin{array}{l}\text { Gásadalur, exposure along the path } \\
\text { Gásadalur-Rógvukollur }\end{array}$ & 100 & $\mathrm{He}-\mathrm{St}$, St-La. & Cl-St-La. & $3-4$ \\
\hline VÁ1 & - do - & 200 & $\mathrm{He}, \mathrm{St}$. & Me, La, An. & $3-4$ \\
\hline VÁ1 & $\begin{array}{l}\text { Gásadalur, exposure at the path Gásadalur- } \\
\text { Rógvukollur }\end{array}$ & 235 & He-Th. & $\mathrm{La}, \mathrm{Ca}$. & $3-4$ \\
\hline VÁ1 & $\begin{array}{l}\text { Gásadalur.The pass between Knúkarnir- } \\
\text { Neytaskarð }\end{array}$ & 340 & $\mathrm{He}, \mathrm{St}, \mathrm{Th}, \mathrm{An}, \mathrm{Cl}$. & & $3-4$ \\
\hline VÁ1 & $\begin{array}{l}\text { Grunnadalur, exposure at the branching of } \\
\text { small streams }\end{array}$ & 380 & $\mathrm{Cl}-\mathrm{He}-\mathrm{Th}, \mathrm{Cl}-\mathrm{He}-\mathrm{St}, \mathrm{Cl}-\mathrm{St}-\mathrm{Me}$. & St-La-St. & $3-4$ \\
\hline VÁ1 & Rógvukollur, exposure at the $\mathrm{W}$ slope & 380 & $\begin{array}{l}\mathrm{He}-\mathrm{Me}, \mathrm{Me}-\mathrm{Ch}, \mathrm{Th}-\mathrm{Ch}-\mathrm{Th}, \mathrm{Mo}-\mathrm{He} \text {, } \\
\text { Mo-Ch } \pm \text { Cld. }\end{array}$ & $\mathrm{Me}, \mathrm{Ca}$. & $2-3$ \\
\hline VÁ1 & Neytaskarð, exposure at the SE slope & $400-420$ & As above. & & $2-3$ \\
\hline VÁ1 & The summit of Rógvukollur & 464 & $\begin{array}{l}\mathrm{He}-\mathrm{Me}, \mathrm{Me}-\mathrm{He}-\mathrm{Me}, \mathrm{Th}-\mathrm{Me}, \mathrm{Th}-\mathrm{Ch} \text {, } \\
\text { Me-Ch. }\end{array}$ & & $2-3$ \\
\hline VÁ1 & $\begin{array}{l}\text { Djúpidalur (the NW slope of Eysturtindur), } \\
\text { exposure at stream }\end{array}$ & $470-480$ & $\mathrm{He}-\mathrm{Me}, \mathrm{He}-\mathrm{Ch}, \mathrm{Me}-\mathrm{Ch}, \mathrm{Th}-\mathrm{Ch}$. & & $2-3$ \\
\hline VÁ1 & & 500 & $\mathrm{He}, \mathrm{Me}, \mathrm{Th}, \mathrm{Ch}$. & & $2-3$ \\
\hline VÁ1 & $\begin{array}{l}\text { Grunnadalur, exposure at the end of small } \\
\text { streams }\end{array}$ & 550 & Th-Me*-Ch. & La, Ca. & $2-3$ \\
\hline VÁ1 & Djúpidalur (the NW slope of Eysturtindur) & $600-610$ & $\mathrm{Ce}-\mathrm{Th}-\mathrm{Th}, \mathrm{Ce}-\mathrm{Ch}$. & St-Me-La, Ca. & $2-3$ \\
\hline VÁ1 & $\begin{array}{l}\text { The plateau between Eysturtindur and } \\
\text { Akranesskarð }\end{array}$ & $620-640$ & An, Th, Me, Sm. & & $2-3$ \\
\hline VÁ4 & $\begin{array}{l}\text { Oyrargjógv ferry harbour and the path to } \\
\text { Sørvágur }\end{array}$ & $0-136$ & St-St*. Ep-St. La.Th. Ch. & St. La. & $3-4$ \\
\hline VÁ4 & Large quarry $1 \mathrm{~km} \mathrm{~W}$ of Sørvágur & 10 & $\begin{array}{l}\text { Cl-St-St*. St-La. Mo-He. Mo-Gy. } \\
\text { An-Gy. Me-Me*-Ch. Me-Ap } \pm \text { Sm. }\end{array}$ & He-St-St*. Ep. La, Me. & $3-4$ \\
\hline VÁ4 & Sjatlá, 1.5 km N of Sørvágsvatn & $45-60$ & $\mathrm{Cl}-\mathrm{He}-\mathrm{St} . \mathrm{St}-\mathrm{La} . \mathrm{Ap}$ & & $2-4$ \\
\hline VÁ4 & $\begin{array}{l}\text { Exposure at } \mathrm{N} \text { end of small road from } \\
\text { Sørvágur, just } \mathrm{W} \text { of Sjatlá }\end{array}$ & 114 & $\mathrm{Cl}-\mathrm{St}-\mathrm{Me} . \mathrm{Cl}-\mathrm{An} . \mathrm{Cl}-\mathrm{Ch} \pm \mathrm{Sm}$. & St-La.Ap. & $2-4$ \\
\hline VÁ4 & - do -, exposure at small tributary of Skjatlá & 150 & $\begin{array}{l}\mathrm{Cl}-\mathrm{He}-\mathrm{St} . \mathrm{St}-\mathrm{Ap} . \mathrm{Cl}-\mathrm{Me}-\mathrm{Th} . \mathrm{Cl}-\mathrm{Me}- \\
\mathrm{Ch} . \mathrm{Me}-\mathrm{Ap} . \mathrm{Me}-\mathrm{Ch} .\end{array}$ & Me-Ap.An-Ap. He-Ch. & $3-4$ \\
\hline VÁ4 & - do - & 190 & As above. & & $3-4$ \\
\hline VÁ4 & - do - & 220 & $\mathrm{Cl}-\mathrm{St}-\mathrm{St} * \mathrm{Cl}-\mathrm{He} \pm \mathrm{La}$. Th. & Mo-St. & $3-4$ \\
\hline VÁ4 & End of Breiðá (Oyrargjógv) & 250 & $\mathrm{Ce}-\mathrm{Me} . \mathrm{He}-\mathrm{Me}$ & & $3-4$ \\
\hline VÁ4 & - do - & 304 & $\mathrm{Ce}-\mathrm{Me}-\mathrm{Th} . \mathrm{Ce}-\mathrm{Th}-\mathrm{Ch}$. & Gy-Me. & $2-3$ \\
\hline VÁ4 & $\begin{array}{l}\text { Kvígandalur, exposure at the SE tributary of } \\
\text { Kvígandalsá }\end{array}$ & 250 & An. He-Le. Me-Le. An-Th-Ch. & & $2-3$ \\
\hline VÁ4 & $\begin{array}{l}\text { Husadalur, exposure at the W? tributary of } \\
\text { Kirjuá }\end{array}$ & 275 & An. Me. He. & Me-An. & $2-3$ \\
\hline
\end{tabular}




\begin{tabular}{|c|c|c|c|c|c|}
\hline Profile & Locality & $\begin{array}{l}\text { Altitude } \\
\quad(\mathrm{m})\end{array}$ & Vesicles & Fractures & Zone \\
\hline VÁ4 & $\begin{array}{l}\text { Kvígandalur, exposure at the SE tributary of } \\
\text { Kvígandalsá }\end{array}$ & $300-365$ & An. He. Le. Ch. & & $2-3$ \\
\hline VÁ4 & $\begin{array}{l}\text { The cross between the path Oyrargjógv- } \\
\text { Sørvágur and Sandavágur-Slættanes }\end{array}$ & 436 & Me.Th. St. Ch. & & $2-3$ \\
\hline VÁ7 & Road exposure $3 \mathrm{~km}$ north of Sandavágur & $100-120$ & $\begin{array}{l}\mathrm{Ce}-\mathrm{He}-\mathrm{St} . \mathrm{Ce}-\mathrm{St}-\mathrm{Me} . \mathrm{Ce}-\mathrm{He}-\mathrm{Th} . \\
\mathrm{Ce}-\mathrm{Mo}-\mathrm{St} . \mathrm{Ce}-\mathrm{Me}-\mathrm{St} .\end{array}$ & $\begin{array}{l}\mathrm{Ce}-\mathrm{Mo}-\mathrm{He} . \mathrm{Ce}-\mathrm{He}-\mathrm{St} . \\
\mathrm{Ce}-\mathrm{Me}{ }^{*}-\mathrm{Ch} . \mathrm{Ce}-\mathrm{Ap} .\end{array}$ & $2-4$ \\
\hline VÁ7 & The western slope of Malinstindur & 219 & As above. & & $2-4$ \\
\hline VÁ7 & - do - & 235 & $\mathrm{Ce}-\mathrm{He}-\mathrm{Me} . \mathrm{Ce}-\mathrm{Me}-\mathrm{Gy}$. & St-Ca. & $2-3$ \\
\hline VÁ7 & - do - & 280 & Ce-Me-Ch. \pm Ca. \pm Sm. & & $2-3$ \\
\hline VÁ7 & - do - & 345 & As above. & & $2-3$ \\
\hline VÁ7 & - do - & 386 & Empty vesicles. & & - \\
\hline VÁ7 & - do - & 410 & Ce-He-Me.Th-Me.Th-An. & St. Ch. & $2-3$ \\
\hline VÁ7 & - do - & 500 & As above. & & $2-3$ \\
\hline VÁ7 & - do - & 538 & He.An. Me.Th.Th*. Cld. Ca. & He-Me. Me*. Cld. & $1-2$ \\
\hline VÁ7 & - do - & 563 & Me-Me*.Th*-Ph.Th*-Ch+Le. & & $1-2$ \\
\hline VÁ7 & The summit of Malinstindur & 580 & Ce-Me*. & & $1-2$ \\
\hline VÁ7 & - do - & 620 & He. Me. Ph. Ch.Th. & Ca. Cld. & $1-2$ \\
\hline VÁ7 & - do - & 683 & Me-He. Me*-Ch. Ph-Ch. & & $1-2$ \\
\hline VÁ7 & - do - & 690 & He. Ch. Le.Th. Cld. & & $1-2$ \\
\hline ST2W & $\begin{array}{l}\text { The path Saksun-Haldarsvík: Kvíggjarhamar, } \\
\text { Saksun }\end{array}$ & $0-100$ & He. St.Th. Me. Ch. & St-Ca-St. Gy.Tb. Ok. & $2-3$ \\
\hline ST2W & $\begin{array}{l}\text { The slope of the mountain between Skipá } \\
\text { and Gellingará }\end{array}$ & 150 & $\mathrm{He}-\mathrm{Ch}-\mathrm{Th} . \mathrm{Me}-\mathrm{St}$. & & $2-3$ \\
\hline ST2W & - do - & 200 & Me. Ca. & & $2-3$ \\
\hline ST2W & - do - & 250 & Th-Me. He-Me. Me-Ch. & St. La. & $2-3$ \\
\hline ST2W & - do - & 310 & As above. & & $2-3$ \\
\hline ST2W & - do - & 325 & Me. Me*.Th*-Ch. He-Me. & Ok. Gy. Ca. & $2-3$ \\
\hline ST2W & - do - & 355 & Me-Me*.Th-Me*.Th*-Ch. & & $2-3$ \\
\hline ST2W & - do - & 360 & $\mathrm{Ce}-\mathrm{Th}^{*} . \mathrm{He}-\mathrm{Me}{ }^{*}-\mathrm{Sm}$. & & $1-2$ \\
\hline ST2W & - do - & 380 & An-Th*.Th*-Le. & Me*_Ca. & $1-2$ \\
\hline ST2W & - do - & 407 & $\mathrm{Ce}-\mathrm{Ph}-\mathrm{Ch} . \mathrm{Ce}-\mathrm{Th}{ }^{*}-\mathrm{Ch}$. & & $1-2$ \\
\hline ST2W & - do - & 430 & Th*-Ch. & & $1-2$ \\
\hline ST2W & - do - & 460 & Empty vesicles. & & $0-1$ \\
\hline ST2W & - do - & 555 & Le-Ch.Th-Th*. & & $0-1$ \\
\hline ST2W & Víkarskarð & 600 & Ce.Th. Ch. Cld. & & $0-1$ \\
\hline ST2W & The NE slope of Gívrufelli & 650 & As above. & & $0-1$ \\
\hline ST2W & The summit of Gívrufelli & 701 & As above. & & $0-1$ \\
\hline ST2E & Víkarnes $\mathrm{N}$ of Haldarsvík & $0-30$ & He-St. Ca. & $\mathrm{Ca}-\mathrm{La}$. & $3-4$ \\
\hline ST2E & The SE slope of Fjallið & 100 & As above + Th. Gy. Ok. & To-Gy. La. & $3-4$ \\
\hline ST2E & - do - & 150 & He. Me.Th. & To-St.Th-Gy-Ap. & $2-3$ \\
\hline ST2E & The summit of Fjallið & 180 & $\mathrm{He}-\mathrm{Me} . \mathrm{He}-\mathrm{Th}$ *. Ca. & & $2-3$ \\
\hline
\end{tabular}




\begin{tabular}{|c|c|c|c|c|c|}
\hline Profile & Locality & $\begin{array}{l}\text { Altitude } \\
(\mathrm{m})\end{array}$ & Vesicles & Fractures & Zone \\
\hline ST2E & $\begin{array}{l}\text { The path Haldarsvík-Saksun: exposure } 0.5 \\
\text { km SW of Haldarsvík }\end{array}$ & 148 & He-St. Me. & $\begin{array}{l}\text { Me-Th-Ch. Me-An. } \\
\text { Ph-Le-Ch. }\end{array}$ & $2-3$ \\
\hline ST2E & - do -, exposure $1 \mathrm{~km} \mathrm{SW}$ of Haldarsvík & 200 & He-St. He-Me. & & $2-3$ \\
\hline ST2E & $\begin{array}{l}\text { - do-, exposure at the Svínstiáir tributaries } \\
\text { of Kluftá, } 1 \mathrm{~km} \mathrm{SW} \text { of Haldarsvík }\end{array}$ & 230 & Me.Th. He. & St. Ca. & $2-3$ \\
\hline ST2E & - do -, exposure $1.2 \mathrm{~km} \mathrm{SW}$ of Haldarsvík & 250 & He. Me. Mo. & He. St.Ap. Ca. & $2-3$ \\
\hline ST2E & - do -, exposure $1.5 \mathrm{~km} \mathrm{SW}$ of Haldarsvík & 280 & Me-Th-Me-Gy-Sm. & & $2-3$ \\
\hline ST2E & - do -, exposure $1.8 \mathrm{~km} \mathrm{SW}$ of Haldarsvík & 350 & Me-Th. & & $2-3$ \\
\hline ST2E & - do -, exposure $2 \mathrm{~km} \mathrm{SW}$ of Haldarsvík & 360 & Me-Th. Me-Ph-Ch. & & $2-3$ \\
\hline ST2E & - do -, exposure $2.3 \mathrm{~km} \mathrm{SW}$ of Haldarsvík & 370 & Me-Th.An-Me-Me*. & & $2-3$ \\
\hline ST2E & - do -, exposure $2.5 \mathrm{~km} \mathrm{SW}$ of Haldarsvík & 400 & Th*-Ch. Me-Th*. & $\mathrm{Ph}-\mathrm{Ch} . \mathrm{Ch}+\mathrm{Le}$. & $1-2$ \\
\hline ST2E & - do - & 410 & Me-Me*. Ch-Le-Ch. & & $1-2$ \\
\hline ST2E & The SE slope of Víkartindur & 420 & Me-Me*-Le. Ch-Ph-Sm. & & $1-2$ \\
\hline ST2E & - do - & 440 & Me*.Th-Th*-Ch. & & $1-2$ \\
\hline ST2E & - do - & 500 & Th*. Ch.Cld. & & $0-1$ \\
\hline ST2E & - do - & 540 & As above. & & $0-1$ \\
\hline ST2E & - do - & 620 & As above. & & $0-1$ \\
\hline ST6W & $\begin{array}{l}\text { Road exposure at the main road Kvívík- } \\
\text { Stykkið, } 1.5 \mathrm{~km} \text { E of Kvivík }\end{array}$ & 50 & He. St. La. Me.Th.Ap. & $\begin{array}{l}\text { He. St. Ap. Me*.Th. Ch. } \\
\text { An. }\end{array}$ & $2-4$ \\
\hline ST6W & Tunnel workplace at the village of Leynar & 50 & Me. St. La. & & $2-4$ \\
\hline ST6W & $\begin{array}{l}\text { Exposure at Leynarvatn along the old road } \\
\text { Tórshavn-Vestmanna }\end{array}$ & $60-125$ & He. St.Wa. La. Ce. Cld. & $\begin{array}{l}\text { St. Ca. He. St. St*. La. } \\
\text { Me*,Th, Le. }\end{array}$ & $2-4$ \\
\hline ST6W & $\begin{array}{l}\text { The path Leynarvatn-Hósvík, exposure } 0.3 \\
\text { km NE of Leynarvatn }\end{array}$ & $150-190$ & $\mathrm{Ce}-\mathrm{He}-\mathrm{St} . \mathrm{Ce}-\mathrm{Me}-\mathrm{Gy} . \mathrm{Cld}$. & $\mathrm{Ph}, \mathrm{Gy}, \mathrm{Ap}$ & $2-3$ \\
\hline ST6W & - do -, 0.4 km NE of Leynarvatn & 210 & $\mathrm{Ce}-\mathrm{He}-\mathrm{St} . \mathrm{Ce}-\mathrm{Me}-\mathrm{Th} . \mathrm{Ce}-\mathrm{St}-\mathrm{La}$. & & $2-3$ \\
\hline ST6W & - do -, 0.5 km NE of Leynarvatn & 260 & $\mathrm{Ce}-\mathrm{Me}-\mathrm{Th} . \mathrm{Ce}-\mathrm{He}-\mathrm{Me} . \mathrm{Ce}-\mathrm{He}-\mathrm{Th}$. & $\mathrm{Me}-\mathrm{Ca}$. & $2-3$ \\
\hline ST6W & $\begin{array}{l}\text { The path Leynarvatn-Hósvík, exposure } \\
0.5 \mathrm{~km} \text { NE of Leynarvatn }\end{array}$ & 300 & As above. & & $2-3$ \\
\hline ST6W & - do -, $0.6 \mathrm{~km} \mathrm{NE}$ of Leynarvatn & 340 & As above. & & $2-3$ \\
\hline ST6W & á Halsi, 1 km NE of Leynarvatn & 380 & As above. & & $2-3$ \\
\hline ST6W & - do -, $1.5 \mathrm{~km}$ NE of Leynarvatn & 463 & $\mathrm{Ce}-\mathrm{He}-\mathrm{Me}-\mathrm{Me}{ }^{*} . \mathrm{Ce}-\mathrm{Th}-\mathrm{Ch}$. & & $2-3$ \\
\hline ST6W & - do -, $1.9 \mathrm{~km}$ NE of Leynarvatn & 500 & As above. & & $2-3$ \\
\hline ST6W & - do -, 2 km NE of Leynarvatn & 510 & Me-He-Me*. Me-Me*.Th*-Ch. & $\mathrm{He}-\mathrm{Me}$. & $2-3$ \\
\hline ST6W & Hósvíksskarð & $520-530$ & Th.Th*.Ph. Ch. Le. + Ce. & & $2-3$ \\
\hline ST6W & The SW slope of Bøllufjall & 550 & As above. & & $1-2$ \\
\hline ST6W & The summit of Bøllufjall & 584 & As above. & & $1-2$ \\
\hline ST6W & The SW slope of Gívrufjall & 530 & As above. & & $1-2$ \\
\hline ST6E & Road exps. between við Áir and Hosvík & 15 & $\begin{array}{l}\mathrm{He}-\mathrm{St} * \mathrm{He}-\mathrm{St}-\mathrm{Ap} . \mathrm{He}-\mathrm{St}-\mathrm{Ch} . \mathrm{He}- \\
\text { Th-Ch.Th-St.Th-Ch. Ga-Th.An-Ch. } \\
\text { An-Ap.An-Th.An-Th-Ch } \pm \text { Ce. }\end{array}$ & $\begin{array}{l}\text { He-Ch-St.Th-Gy+Ap. } \\
\text { Ch-Th*-Ap. }\end{array}$ & $2-3$ \\
\hline ST6E & The path Hosvík-Leynar: Smørdalsá & $160-203$ & $\mathrm{He}-\mathrm{Me} . \mathrm{He}-\mathrm{Ch}-\mathrm{Th}, \mathrm{Me}-\mathrm{G} y . \mathrm{He}-\mathrm{An}-\mathrm{Th}$. & & $2-3$ \\
\hline
\end{tabular}




\begin{tabular}{|c|c|c|c|c|c|}
\hline Profile & Locality & $\begin{array}{l}\text { Altitude } \\
(\mathrm{m})\end{array}$ & Vesicles & Fractures & Zone \\
\hline ST6E & The path Hosvík-Leynar: Smørdalsá & $240-260$ & Ce-Me-He. Ce-Th-Me. Cld. & Me-Th-Ap-Gy. & $2-3$ \\
\hline ST6E & - do - & 360 & As above. & Ca-La. Cld. & $2-3$ \\
\hline ST6E & $\begin{array}{l}\text { The NE slope between Bøllufjall and } \\
\text { Gívrufjall }\end{array}$ & 436 & Me-Th. He-Me-Ca. He-Th. & & $2-3$ \\
\hline ST6E & - do - & 480 & He-Me-Me*.Th-Ch.Th-Th*. & & $2-3$ \\
\hline ST6E & - do - & 500 & Th-Th*-Gy. Me*-Gy. & & $2-3$ \\
\hline ST6E & The NE slope of Bøllufjall & 530 & Th-Th*.Th-Ph,Th*-Ch. & & $1-2$ \\
\hline ST6E & The summit of Bøllufjall & 584 & As above. & & $1-2$ \\
\hline ST10 & $\begin{array}{l}\text { Large quarry } 0.5-1 \mathrm{~km} \mathrm{NW} \text { of Sund, } \\
\text { Kalsbaksfjørður }\end{array}$ & 15 & Me.Me*.Th.An. Ph. Gi.Ap. & & $2-3$ \\
\hline ST10 & Exposure at Sundá, $1.2 \mathrm{~km} \mathrm{~S}$ of Sund & 227 & He. Me. Ca. & & $2-3$ \\
\hline ST10 & - do,$- 1.6 \mathrm{~km} \mathrm{SW}$ of Sund & 265 & Me.Th. & St-He. & $2-3$ \\
\hline ST10 & $\begin{array}{l}\text { Quarry } 0.5 \mathrm{~km} \mathrm{SW} \text { of Lambafelli at the high } \\
\text { road Tórshavn-Kollafjørður }\end{array}$ & 340 & $\mathrm{Ce}-\mathrm{He} . \mathrm{Ce}-\mathrm{Ch}-\mathrm{Le} . \mathrm{Ce}-\mathrm{An} . \mathrm{Ce}-\mathrm{Ch}$. & $\begin{array}{l}\mathrm{Ce}-\mathrm{He}-\mathrm{Sm}, \mathrm{Ce}-\mathrm{He}-\mathrm{Ch} . \\
\mathrm{Ce}-\mathrm{He}-\mathrm{Th}-\mathrm{Ch} .\end{array}$ & $2-3$ \\
\hline ST10 & $\begin{array}{l}\text { Road exps. } 1 \mathrm{~km} \mathrm{~W} \text { of Sundshálsur along the } \\
\text { high road Tórshavn-Kollafjørður }\end{array}$ & 310 & $\mathrm{Ce}-\mathrm{He}-\mathrm{Me} . \mathrm{Ce}-\mathrm{Me}-\mathrm{Ch} . \mathrm{Ce}-\mathrm{Th}-\mathrm{Me}$. & & $2-3$ \\
\hline ST10 & $\begin{array}{l}\text { Small quarry at end of road to the water } \\
\text { reservoir of Havnardalur }\end{array}$ & 170 & He. Me.Th. Ch. & & $2-3$ \\
\hline ST10 & $\begin{array}{l}\text { Road exposure at the road Tórshavn- } \\
\text { Velbastaður, } 0.5 \mathrm{~km} \mathrm{~N} \text { of Velbastaður }\end{array}$ & 160 & Ce-Me. Ce-Th-Ch. & & $2-3$ \\
\hline ST10 & $\begin{array}{l}\text { Exposure at the road Tórshavn-Velbastaður, } \\
\text { just } \mathrm{N} \text { of Velbasta ur }\end{array}$ & 123 & $\begin{array}{l}\text { Me-Me*.Me-Ch. Me.Th-Ch.Th-Me- } \\
\text { Me*. }\end{array}$ & Cld, Ca. & $2-3$ \\
\hline EY1 & $\begin{array}{l}\text { Road exposure at the road Eiði-Norðskáli, } \\
0.4-0.5 \mathrm{~km} \mathrm{SE} \text { of Eiði }\end{array}$ & $60-100$ & $\begin{array}{l}\text { Ap-Gy-Me. Me-Ph. He-Gy-Me. He- } \\
\text { Me-Ch. St-Aå-Sm.Th-Ap.Th-St-Ap. } \\
\text { Th-Ch-Sm. }\end{array}$ & $\begin{array}{l}\text { St-La-St*-Ca. He-St- } \\
\text { Ch-Sm. }\end{array}$ & $3-4$ \\
\hline EY1 & $\begin{array}{l}\text { Localities on the road Eiði-Funningur: } \\
\text { Quarry in Djúpidalur, } 2 \mathrm{~km} \text { east of Eiði }\end{array}$ & 150 & $\begin{array}{l}\text { St-Gy. St-Th-Gy.Th-Ga-Th. Me-Th. } \\
\text { Me-Ch. }\end{array}$ & St-La. & $3-4$ \\
\hline EY1 & $\begin{array}{l}50 \mathrm{~m} \text { long road cutting on } \mathrm{W} \text { slope of } \\
\text { Slættaratindur, } 3.5 \mathrm{~km} \text { east of Eiði }\end{array}$ & $200-230$ & $\begin{array}{l}\text { Me-Th*-Gy. Me-Th*-Ch. Me-He-Me. } \\
\text { He-Me. }\end{array}$ & $\begin{array}{l}\text { St-St*. La-Me*-Sm. } \\
\text { He-Ap. St. Cld. Qz. }\end{array}$ & $2-3$ \\
\hline EY1 & $\begin{array}{l}\text { Road exposure } 0.4-0.5 \mathrm{~km} E \text { of Eiðisskarð } \\
\text { just at the } \mathrm{N} \text { slope of Vaðhorn }\end{array}$ & $336-346$ & $\mathrm{Ce}-\mathrm{Me}-\mathrm{Th} *$. Ce-Me-Ch. & & $2-3$ \\
\hline EY1 & The N slope of Vaðhorn & 410 & As above. & $\mathrm{He}-\mathrm{St}-\mathrm{St} *$ Mo-St. & $2-3$ \\
\hline EY1 & - do - & 435 & As above. & & $2-3$ \\
\hline EY1 & $\begin{array}{l}\text { Small quarry at the road fork Eiði, Funningur, } \\
\text { Gjógv, } 1 \mathrm{~km} \text { west of Funningur (165) }\end{array}$ & 165 & He. St. Me. Me*. Ch. & & $2-4$ \\
\hline EY1 & Exposure at the coast line at Funningur & $5-10$ & Mo. He. St. Me. +Ce. & St. An. Me. Cld. & $3-4$ \\
\hline EY2 & $\begin{array}{l}\text { Exposure at the coast between Stórá and } \\
\text { Marká }\end{array}$ & $0-20$ & Mo. He. St. & St. Qz. Cld. Ca. & $3-4$ \\
\hline EY2 & The path Svínár-Funningur & $30-40$ & He-Me. He-St-Gy. He-Me-Gy. & & $3-4$ \\
\hline EY2 & - do - & 100 & $\begin{array}{l}\text { Me-Th-Ch.Th-Gi.Th-Me*.An-Ch. } \\
\text { An-Th-Ch. }\end{array}$ & Th-Gy-Ap. Me-Ap-St. & $2-3$ \\
\hline EY2 & - do - & 212 & As above. & & $2-3$ \\
\hline EY2 & - do - & 280 & Me.Th.An. Ch. & An-Th*-Gy. & $2-3$ \\
\hline EY2 & - do - & 346 & An. Me. Me*.Th.Th*.Th-Ch-Sm. & & $2-3$ \\
\hline EY2 & - do - & 400 & $\mathrm{Ce}-\mathrm{Th}-\mathrm{Th}{ }^{*}-\mathrm{Ch} . \mathrm{Ce}-\mathrm{Ch}$. & Th-Th*-Ch. & $1-2$ \\
\hline EY2 & - do - & 420 & Ch-An. Ch.Gi-Th*.An-Ph-Ch. & & $1-2$ \\
\hline
\end{tabular}




\begin{tabular}{|c|c|c|c|c|c|}
\hline Profile & Locality & $\begin{array}{l}\text { Altitude } \\
(\mathrm{m})\end{array}$ & Vesicles & Fractures & Zone \\
\hline EY2 & Kvígandalsskarð & 460 & Me*.Th*. Ch. Gy. Sm. & & $1-2$ \\
\hline EY2 & - do - & 480 & As above. & & $1-2$ \\
\hline EY2 & The E slope of Skerðingur & 500 & As above. & & $1-2$ \\
\hline EY2 & - do - & 525 & As above. & & $1-2$ \\
\hline EY2 & - do - & 450 & $\mathrm{Ce}-\mathrm{Th} * \mathrm{Ce}-\mathrm{Me}-\mathrm{Me}{ }^{*}-\mathrm{Ch}$. & & $1-2$ \\
\hline EY2 & - do - & 430 & As above. & & $2-3$ \\
\hline EY2 & - do - & 415 & Ce-An. Ce-Qz. Cld. & & $2-3$ \\
\hline EY2 & - do - & 380 & Me. & & $2-3$ \\
\hline EY2 & Kvígandalur & 363 & He-Me. He-Th. & & \\
\hline EY2 & Skipagjógv & 180 & Me-Th-Th*. Ch-Gi-Th. & $\begin{array}{l}\text { An-Th-Ap-Gy-Sm. } \\
\text { Cl. Ca. }\end{array}$ & $2-3$ \\
\hline EY2 & - do - & 80 & He. Me.Th. & Ca. & $2-3$ \\
\hline EY2 & - do - & 50 & Gy-He. Gy-Th-Me. & & $3-4$ \\
\hline EY2 & Skipagjósoyran & $0-10$ & He. St.Th. La. Gy. & He. Me-La-St. & $3-4$ \\
\hline EY3 & Large quarry $1 \mathrm{~km} \mathrm{~S}$ of Oyri & $20-30$ & $\begin{array}{l}\text { Me-Th-Sm. Me-Th-Ch-Sm. Me-Gy- } \\
\text { Me*. }\end{array}$ & $\mathrm{Cl}-\mathrm{He}-\mathrm{Th}-\mathrm{Ap}$. & $2-3$ \\
\hline EY3 & Oyrargjógv & 100 & Me-Th, Me-Gy. & & $2-3$ \\
\hline EY3 & - do - & 210 & No vesicles. & He. St. Me.Th. Gy. & $2-3$ \\
\hline EY3 & The path Oyri-Skálafjørður & 251 & Me.Th. Ch. & & $2-3$ \\
\hline EY3 & - do - & 300 & He-Me.Th-Me.Th-Ch. & & $2-3$ \\
\hline EY3 & - do - & 340 & An. Me*-Ch. & & $1-2$ \\
\hline EY3 & - do - & 350 & Me*_Ch.Th-Th*. & & $1-2$ \\
\hline EY3 & - do - & 400 & Th-St-Gy. Ch. St. & & $1-2$ \\
\hline EY3 & - do - & 426 & $\mathrm{An}-\mathrm{Th} * . \mathrm{An}-\mathrm{Th} *-\mathrm{Ca} . \mathrm{Ch}$. & & $1-2$ \\
\hline EY3 & - do - & 495 & Th*-Ch+Le. & & $1-2$ \\
\hline EY3 & The SW slope of Sandfelli & 527 & $\mathrm{Ce}-\mathrm{Th} *-\mathrm{Ch} . \mathrm{Ce}-\mathrm{Cld}$. & He. Me. Ca. Cld. & $0-1$ \\
\hline EY3 & - do - & 545 & As above. & As above. & $0-1$ \\
\hline EY3 & The summit of Sandfelli & 572 & As above. & As above. & $0-1$ \\
\hline EY3 & The path on the S slope of Skálafjall & 440 & Me-Th. He-Me. & & $2-3$ \\
\hline EY3 & - do - & 405 & As above. & & $2-3$ \\
\hline EY3 & - do -, just at Öksnagjógv & 200 & As above. & & $2-3$ \\
\hline EY4 & $\begin{array}{l}\text { Small quarry just } N \text { of Morskarnes, about } \\
1 \mathrm{~km} \mathrm{~N} \text { of Nesá }\end{array}$ & 20 & He-Th-Ch. Me-Th. & He-St. He-Ap. Ca. & $2-3$ \\
\hline EY4 & $\begin{array}{l}\text { The W slope of Neshagi, just E of the locality } \\
\text { above }\end{array}$ & 140 & $\mathrm{Cl}-\mathrm{Me}-\mathrm{Th} . \mathrm{He}-\mathrm{Th}$. & & $2-3$ \\
\hline EY4 & Exposure at Skotá & 194 & As above. & & $2-3$ \\
\hline EY4 & - do - & 230 & Me-Me*. Ch. & & $1-2$ \\
\hline EY4 & - do - & 320 & Th*.Me-Me*.Ch. & $\mathrm{He}-\mathrm{Me} . \mathrm{He}-\mathrm{St}$. & $1-2$ \\
\hline EY4 & $\begin{array}{l}\text { The SE slope of Kambur: exposure between } \\
\text { the source of Skotá and Urðará }\end{array}$ & 380 & Me*. Ch, Le +Ce. & & $1-2$ \\
\hline
\end{tabular}




\begin{tabular}{|c|c|c|c|c|c|}
\hline Profile & Locality & $\begin{array}{l}\text { Altitude } \\
(\mathrm{m})\end{array}$ & Vesicles & Fractures & Zone \\
\hline EY4 & $\begin{array}{l}\text { The SE slope of Kambur: exposure between } \\
\text { the source of Skotá and Urðará }\end{array}$ & 400 & As above. & & $1-2$ \\
\hline EY4 & - do - & 430 & Th*. Ch. Le. Ce. & & $0-1$ \\
\hline EY4 & - do - & 462 & Ch. Many empty vesicles. & & $0-1$ \\
\hline EY4 & The path Steffanstangi-Kambur & 480 & As above. & & $0-1$ \\
\hline EY4 & - do - & 500 & Th-Ch-Th*. Cld. Ca. & & $0-1$ \\
\hline EY4 & - do - & 540 & As above. & & $0-1$ \\
\hline EY4 & $\begin{array}{l}\text { The summit of Kambur (trigonometric } \\
\text { station) }\end{array}$ & 593 & As above. & & $0-1$ \\
\hline EY4 & The E slope of Heygshagi & 440 & Me*-Ch.Th*-Ch. & & $1-2$ \\
\hline EY4 & - do - & 400 & As above. & & $1-2$ \\
\hline EY4 & - do - & 250 & As above. & & $1-2$ \\
\hline EY4 & Markrá & 250 & Me-Me*. He-Th. He-Me*. & & $2-3$ \\
\hline EY4 & - do - & 160 & As above. & & $2-3$ \\
\hline EY8 & $\begin{array}{l}\text { Road exposure at the old road Lervík- } \\
\text { Fuglafjørður/Norðragøta, about } 2 \mathrm{~km} \mathrm{NW} \\
\text { of Lervík }\end{array}$ & 80 & $\mathrm{Ce}-\mathrm{Mo}-\mathrm{He}-\mathrm{Me}$. Ce-Ch. & $\mathrm{He}-\mathrm{Me}-\mathrm{St}$. & $2-3$ \\
\hline EY8 & Localities along Kálvadalsá in Kálvadalur & 200 & $\begin{array}{l}\text { Mo-He-Me-Me*.An-Th-Ch. } \\
\text { Le-Ch-Le. }\end{array}$ & $\mathrm{He}-\mathrm{Me}-\mathrm{St}-\mathrm{St} *$.An-Th. & $2-3$ \\
\hline EY8 & - do - & 270 & As above. & & $2-3$ \\
\hline EY8 & - do - & 300 & He-Me*-Ch.An-Th*_Ch. & & $2-3$ \\
\hline EY8 & Mannsgjógv & 400 & $\mathrm{An}-\mathrm{Ph}-\mathrm{Ch} . \mathrm{An}-\mathrm{Th}-\mathrm{Ch}, \mathrm{Me}{ }^{*}-\mathrm{An}$. & & $1-2$ \\
\hline EY8 & The NE slope of Navirnar & 300 & $\mathrm{He}-\mathrm{Me}-\mathrm{St} * \mathrm{He}-\mathrm{Ch}, \mathrm{He}-\mathrm{Le} . \mathrm{An}-\mathrm{He}$. & He-St. He-Me. & $2-3$ \\
\hline EY8 & The E slope of Ritafjall & 440 & He-Me*-Ch.An-Th*-Ch. & & $1-2$ \\
\hline EY8 & - do - & 490 & $\mathrm{He}-\mathrm{Th}-\mathrm{Ch} . \mathrm{Me} \mathrm{e}^{*} \mathrm{St}^{*}$. & & $1-2$ \\
\hline EY8 & - do - & 520 & Th-Ch. Me*-Ch. & He. St. Ca. & $0-1$ \\
\hline EY8 & The summit of Ritafjall & 560 & Th.Ch. Le. & & $0-1$ \\
\hline EY8 & - do - & 641 & Th*. Nearly all vesicles are empty. & & $0-1$ \\
\hline EY10 & $\begin{array}{l}\text { Large quarry just } \mathrm{N} \text { of the road fork } \\
\text { Skálafjørður-Runavík-Lambi }\end{array}$ & $60-80$ & $\begin{array}{l}\text { Me-St*.Th-St*.Th-Me-An.Th-Ch-St*. } \\
\text { Co-Th. Ha. }\end{array}$ & $\begin{array}{l}\mathrm{He}-\mathrm{St} * \mathrm{He}-\mathrm{Th}-\mathrm{Ca} . \\
\mathrm{Ph}-\mathrm{Ch}-\mathrm{Ph} . \mathrm{Ha}-\mathrm{Ca} .\end{array}$ & $2-3$ \\
\hline EY10 & $\begin{array}{l}\text { The SW slope of Ritafelli, NE of the locality } \\
\text { above }\end{array}$ & 180 & No vesicles. & $\begin{array}{l}\mathrm{He}-\mathrm{Me}-\mathrm{Ch}-\mathrm{Sm} \\
\mathrm{Me} \text { - } \mathrm{Le}-\mathrm{Ch}-\mathrm{Sm} \\
\mathrm{An}-\mathrm{Me} \text { - }-\mathrm{Sm}\end{array}$ & $2-3$ \\
\hline EY10 & - do - & 200 & Me-Me*. Ch.Th*. Ph. & $\begin{array}{l}\text { An-Me*-Sm. Me*-Ph- } \\
\text { Le.Ap-Sm. }\end{array}$ & $1-2$ \\
\hline EY10 & - do - & $230-240$ & As above. & & $1-2$ \\
\hline EY10 & - do - & 270 & $\begin{array}{l}\text { He-Th-Ch.Th*-Ph.An-Th*, Ch-St. } \\
\text { An-St.Ap-Th-Ph. Ca. }\end{array}$ & St-La. Me-Ap. & $1-2$ \\
\hline EY10 & The edge of Ritafelli & 350 & St, Me*.Th*. Ph. Ch. Ce. & & $1-2$ \\
\hline EY10 & The SW slope of Stórafjall & 380 & Th*. Ch. Ph. & & $1-2$ \\
\hline EY10 & The W edge of Stórafjall & 440 & Th. Ph. Ch.An. Ce. & An. St. Ch. Ph. Sm. & $0-1$ \\
\hline EY10 & - do - & 490 & Empty vesicles. & St, Th*. Ch. Ca. Cld. Sm. & $0-1$ \\
\hline
\end{tabular}




\begin{tabular}{|c|c|c|c|c|c|}
\hline Profile & Locality & $\begin{array}{l}\text { Altitude } \\
(\mathrm{m})\end{array}$ & Vesicles & Fractures & Zone \\
\hline EY10 & The W edge of Stórafjall & 520 & Th. Many empty vesicles. & & $0-1$ \\
\hline EY10 & The summit of Stórafjall & 567 & As above. & & $0-1$ \\
\hline BO1 & Large quarries at Klakkur & 60 & Me-Ch. He-Me. Cld. & Mo-St-La. Ca-St. & $2-3$ \\
\hline BO1 & The NE slope of Klakkur & 100 & Mo-An. Mo-He. Me-Ch. Ca. & & $2-3$ \\
\hline BO1 & - do - & 140 & Me-Th*. Ga-Me. Ch-Gi-Th. & As in the vesicles. & $2-3$ \\
\hline BO1 & The NE slope of Klakkur & 160 & Th-Me*_Ph. Ph-Ch. & $\mathrm{He}-\mathrm{St} . \mathrm{Ca}-\mathrm{St}$. & $1-2$ \\
\hline BO1 & - do - & 210 & Mo-He-Ch. Ch-Th.Th-Ph. Le-Ch. & $\mathrm{Ca}-\mathrm{St}$. & $1-2$ \\
\hline BO1 & - do - & 260 & Me-Th-La.An-St-La.An-Th-Ch. & & $2-3$ \\
\hline BO1 & The summit of Klakkur & 414 & Ch-Th.Th-Ph. & & $2-3$ \\
\hline BO1 & The S slope of Klakkur & 380 & As above. & & $2-3$ \\
\hline BO1 & - do - & 300 & Me-Th.Th*-Ch.Th-Ph-Ch. & He-St-La. & $2-3$ \\
\hline BO1 & - do - & 260 & $\mathrm{He}-\mathrm{Me}-\mathrm{Th} . \mathrm{He}-\mathrm{Th}$. & & $2-3$ \\
\hline BO1 & The NE slope of Hálgafelli & 280 & $\mathrm{Ce}-\mathrm{He}-\mathrm{Me}-\mathrm{St} . \mathrm{Ce}-\mathrm{Me}-\mathrm{An}$. & & $2-3$ \\
\hline BO1 & - do - & 300 & As above. & & $2-3$ \\
\hline BO1 & - do - & 360 & As above. & & $2-3$ \\
\hline BO1 & - do - & 380 & $\mathrm{Ce}-\mathrm{Mo}-\mathrm{He}-\mathrm{Th} . \mathrm{Ce}-\mathrm{He}-\mathrm{Me}$. & & $2-3$ \\
\hline BO1 & - do - & 400 & Ce-St-Ch. & $\mathrm{He}-\mathrm{Th}-\mathrm{Me}-\mathrm{St}$. & $2-3$ \\
\hline BO1 & - do - & 450 & As above. & & $2-3$ \\
\hline BO1 & - do - & 480 & An-Me-Me*.Th-Ch. & & $2-3$ \\
\hline BO1 & The summit of Hálgafelli & 503 & $\mathrm{Ce}-\mathrm{He}-\mathrm{Me}$. & St-La. & $2-3$ \\
\hline $\mathrm{BO} 2$ & Exposure at stream $0.6 \mathrm{~km} \mathrm{SW}$ of Norðoyri & $20-80$ & He. Me. Ch.An.Ap. & St. Cld. Ca. & $2-3$ \\
\hline BO2 & The W slope of Høgahædd & 140 & An. Me. Ch. Many empty vesicles. & As above. & $1-3$ \\
\hline BO2 & - do - & 220 & He-St. He-Ch-St. Th-Ph. & St. Ca. & $2-4$ \\
\hline $\mathrm{BO} 2$ & - do - & 270 & Empty vesicles. & & - \\
\hline BO2 & - do - & 310 & $\mathrm{He}-\mathrm{Me}-\mathrm{Me}$ *. Me-An. Me-Ch. & & $2-3$ \\
\hline BO2 & - do - & 320 & Ch-Th*-Ch. He-Ch.Th*.An. & & $1-2$ \\
\hline $\mathrm{BO} 2$ & - do - & 330 & Me*.Th'. Ch. Ca. & & $1-2$ \\
\hline $\mathrm{BO} 2$ & - do - & 360 & As above. & Ch.Th*. Ca. & $1-2$ \\
\hline $\mathrm{BO} 2$ & - do - & 440 & Th*. Ca. Op. & Cld. & $1-2$ \\
\hline $\mathrm{BO} 2$ & - do - & 474 & Me. Me*.Th*. Ch. & & $1-2$ \\
\hline $\mathrm{BO} 2$ & - do - & 510 & Th-Th*. Ca. Cld. Many empty vesicles. & & $0-1$ \\
\hline $\mathrm{BO} 2$ & - do - & 550 & As above. & & $0-1$ \\
\hline $\mathrm{BO} 2$ & The summit of Høgahædd & 563 & As above. & & $0-1$ \\
\hline $\mathrm{BO} 3$ & Large quarry between Norðdepil and Depil & $40-50$ & $\mathrm{Ce}-\mathrm{He}-\mathrm{Th} . \mathrm{Ce}-\mathrm{He}-\mathrm{Na}-\mathrm{Th} . \mathrm{Ce}-\mathrm{Th}-\mathrm{Ch}$. & $\begin{array}{l}\mathrm{Cl}-\mathrm{He}-\mathrm{St}-\mathrm{Ap} . \mathrm{Cl}-\mathrm{Th}- \\
\text { Ap. Cl-Ph. }\end{array}$ & $2-4$ \\
\hline $\mathrm{BO} 3$ & Depilsá & 150 & Me-Me*-Ch-Le. Me-Me*-Ch. He-Me. & & $2-3$ \\
\hline $\mathrm{BO} 3$ & - do - & 200 & Me*-Ch,An-Ch. & & $1-2$ \\
\hline $\mathrm{BO} 3$ & - do - & 300 & $\begin{array}{l}\mathrm{He}-\mathrm{Me}{ }^{*}-\mathrm{Ch} . \mathrm{He}-\mathrm{Th}{ }^{*}-\mathrm{Ch} . \mathrm{An}-\mathrm{Ph}-\mathrm{Ch} . \\
+\mathrm{Ce} .\end{array}$ & He-St. He-Th-Ca. & $1-2$ \\
\hline
\end{tabular}




\begin{tabular}{|c|c|c|c|c|c|}
\hline Profile & Locality & $\begin{array}{l}\text { Altitude } \\
(\mathrm{m})\end{array}$ & Vesicles & Fractures & Zone \\
\hline $\mathrm{BO} 3$ & Depilsá & 340 & As above. & & $1-2$ \\
\hline $\mathrm{BO} 3$ & E slope of Lokki & 375 & Ch-Gi-Th'. Ch-An. & & $0-1$ \\
\hline $\mathrm{BO} 3$ & - do - & 400 & Ch-Th*-Ch. Ch-Le. & & $0-1$ \\
\hline BO3 & - do - & 450 & As above. & & $0-1$ \\
\hline $\mathrm{BO} 3$ & - do - & 470 & Th. Ch. Ca. & $\mathrm{He}-\mathrm{St}-\mathrm{Th}-\mathrm{Ca}$. & $0-1$ \\
\hline $\mathrm{BO} 3$ & E slope of Lokkanøv & 460 & $\begin{array}{l}\text { Ce-An-Ch. Ce-Th-Ch-Th*. Many } \\
\text { empty vesicles. }\end{array}$ & & $0-1$ \\
\hline $\mathrm{BO} 3$ & - do - & 580 & As above. & & $0-1$ \\
\hline $\mathrm{BO} 3$ & - do - & 700 & As above. & & $0-1$ \\
\hline $\mathrm{BO} 3$ & The summit of Lokki (trigonometric station) & 754 & As above. & & $0-1$ \\
\hline VI1 & $\begin{array}{l}\text { The starting point of the profile is the } \\
\text { largest stream } 0.5 \mathrm{~km} \text { SE of Hvannasund }\end{array}$ & 50 & $\begin{array}{l}\text { Ce-Me-St. Ce-An-Th-Me. Ce-Me-Ch. } \\
\text { Ce-He-St-Me. }\end{array}$ & $\begin{array}{l}\mathrm{Ce}-\mathrm{Cl}-\mathrm{St} . \mathrm{Ce}-\mathrm{Cl}-\mathrm{Me}- \\
\mathrm{Ca} .\end{array}$ & $2-3$ \\
\hline VI1 & SW slope of Enni & $120-132$ & Empty vesicles. & & - \\
\hline VI1 & SW slope of Enni & 180 & Mo-An. & & $2-3$ \\
\hline $\mathrm{V} \mid 1$ & - do - & 210 & $\begin{array}{l}\text { An. Ph-Ch.An-Th. Me-Me*. He-Me- } \\
\text { Ch. }\end{array}$ & $\begin{array}{l}\mathrm{He}-\mathrm{Me}{ }^{*}-\mathrm{Ch} . \mathrm{He}-\mathrm{Ph}- \\
\text { Ch. He-Th-Me. }\end{array}$ & $2-3$ \\
\hline VI1 & - do - & 225 & As above. & & $1-2$ \\
\hline VI1 & - do - & 240 & Me*.Th*.An. & & $1-2$ \\
\hline VI1 & - do - & 270 & $\begin{array}{l}\mathrm{Ce}-\mathrm{Th}-\mathrm{Th}{ }^{*}-\mathrm{Ch} . \mathrm{Ce}-\mathrm{Ch}-\mathrm{Le} . \mathrm{Ce}-\mathrm{An}- \\
\mathrm{Ch} . \mathrm{Ce}-\mathrm{Ch}-\mathrm{St} . \mathrm{Ce}-\mathrm{He} . \mathrm{Ce}-\mathrm{He}-\mathrm{Cld} .\end{array}$ & He-St. Cld. & $1-2$ \\
\hline VI1 & - do - & 310 & Ch-Gi-Th*. St-Ch. Ph-Ch.Th-Th*. & & $1-2$ \\
\hline VI1 & - do - & 360 & Ce-Ch. Ce-Ph-Ch. Ce-Th*. Ch. & & $1-2$ \\
\hline VI1 & - do - & 380 & Ch.Th. Le. Sm. & Cld. & $1-2$ \\
\hline VI1 & - do - & 420 & Th*-Le-Ch-Sm. & Op. Sm. & $0-1$ \\
\hline VI1 & - do - & 550 & As above. Many empty vesicles. & & $0-1$ \\
\hline VI1 & - do - & 600 & $\mathrm{Ca}$ and Siderite. & & $0-1$ \\
\hline VI1 & The summit of Enni & 651 & As above. & & $0-1$ \\
\hline $\mathrm{V} \mid 2$ & $\begin{array}{l}\text { Small quarry at the road Hvannasund- } \\
\text { Viðareiði, } 2.6 \mathrm{~km} \mathrm{~N} \text { of Hvannasund }\end{array}$ & $40-80$ & $\begin{array}{l}\mathrm{Ce}-\mathrm{He}-\mathrm{Me} . \mathrm{Ce}-\mathrm{He}-\mathrm{Th} . \mathrm{Ce}-\mathrm{He}- \\
\mathrm{Ch}-\mathrm{Sm} . \mathrm{Ce}-\mathrm{Ch}-\mathrm{Sm} . \mathrm{Ce}-\mathrm{Ph}-\mathrm{Me}{ }^{*} \\
\mathrm{Ce}-\mathrm{Me}-\mathrm{Me} \text {. }\end{array}$ & $\mathrm{He}-\mathrm{Me}-\mathrm{St}$. & $2-3$ \\
\hline $\mathrm{V} I 2$ & W slope of Tunnafjall & $80-100$ & $\begin{array}{l}\mathrm{He}-\mathrm{Me}-\mathrm{Me}{ }^{*} . \mathrm{An}-\mathrm{Th}-\mathrm{Me} . \mathrm{An}-\mathrm{Th}-\mathrm{Ch} . \\
\mathrm{An}-\mathrm{Ph}-\mathrm{Ch} .\end{array}$ & He-St. St-Me. & $2-3$ \\
\hline $\mathrm{V} 12$ & - do - & 150 & As above. & & $1-2$ \\
\hline $\mathrm{V} \mid 2$ & - do - & 200 & As above. & & $1-2$ \\
\hline $\mathrm{V} \mid 2$ & - do - & 225 & Me*.Th*. Ch. Ph.An. & He. St. Ca. & $1-2$ \\
\hline $\mathrm{V} \mid 2$ & - do - & 250 & Me*.Th*.Ch. & & $1-2$ \\
\hline $\mathrm{V} \mid 2$ & - do - & 300 & Th*. Ch. & & $1-2$ \\
\hline $\mathrm{VI} 2$ & - do - & 315 & As above. & & $0-1$ \\
\hline $\mathrm{VI} 2$ & - do - & 390 & An.Th'. Ch. Ph. & Me*.Ph. St. & $0-1$ \\
\hline $\mathrm{V} / 2$ & - do - & 460 & Th*. Ch. Le. Sm. & St. Sm. & $0-1$ \\
\hline $\mathrm{V} \mid 2$ & - do - & $520-550$ & Empty vesicles. & Qz. Cld. Ca. & $0-1$ \\
\hline
\end{tabular}




\begin{tabular}{|c|c|c|c|c|c|}
\hline Profile & Locality & $\begin{array}{l}\text { Altitude } \\
(\mathrm{m})\end{array}$ & Vesicles & Fractures & Zone \\
\hline $\mathrm{VI} 2$ & The summit of Tunnafjall & 593 & Th.Th*. Ch. & & $0-1$ \\
\hline VI2 & The S Slope of Myrnafjall & 620 & No vesicles. & Th.Th*. & $0-1$ \\
\hline $\mathrm{V} 12$ & $\begin{array}{l}\text { The summit of Myrnafjall (trigonometric } \\
\text { station) }\end{array}$ & 688 & $\begin{array}{l}\text { Th. Th*. Only } 20 \% \text { of the vesicles are } \\
\text { mineralised. }\end{array}$ & & $0-1$ \\
\hline $\mathrm{VI3}$ & $\begin{array}{l}\text { Small quarry at the roadViðareiði- } \\
\text { Hvannasund, } 2.5 \mathrm{~km} \text { south of Viðareiði }\end{array}$ & 80 & $\mathrm{He}-\mathrm{Th}^{*} . \mathrm{Me}-\mathrm{Me} \mathrm{e}^{*} \mathrm{Ch}-\mathrm{Se}$. & As in the vesicles. & $1-2$ \\
\hline VI3 & The W and the SW slope of Malinsfjall & 150 & He-Th*.Me-Me*-Ch.An-Me*-Ph. & & $1-2$ \\
\hline $\mathrm{VI3}$ & - do - & $200-220$ & Th*. Ch. Le. & Me.Me*.Th.Th*.An. St. & $0-1$ \\
\hline $\mathrm{V} \mid 3$ & - do - & 255 & Th*.Ph.An. & $\mathrm{He}-\mathrm{St}$. & $1-2$ \\
\hline $\mathrm{V} 13$ & The W and the SW slope of Malinsfjall & 310 & Th*-Ch. & & $0-1$ \\
\hline $\mathrm{V} 13$ & - do - & $300-330$ & Me-Th*. Gi-Ch. & & $0-2$ \\
\hline $\mathrm{V} 13$ & - do - & 440 & $\begin{array}{l}\text { Th*. Ch. About } 50 \% \text { of the vesicles are } \\
\text { empty. }\end{array}$ & An-St. & $0-1$ \\
\hline $\mathrm{V} 13$ & - do - & 540 & As above. & & $0-1$ \\
\hline $\mathrm{V} \mid 3$ & - do - & 605 & Ch-Th-Le. Ca. & $\mathrm{Ca}-\mathrm{Th}-\mathrm{Ca}$. & $0-1$ \\
\hline $\mathrm{V} 13$ & - do - & 660 & All vesicles are empty. & & $0-1$ \\
\hline $\mathrm{V} 13$ & - do - & 680 & As above & & $0-1$ \\
\hline $\mathrm{V} 13$ & - do - & 710 & Scattered mineralisations of Th and Ch. & & $0-1$ \\
\hline $\mathrm{VI3}$ & The summit of Malinsfjall & 750 & As above. & & $0-1$ \\
\hline
\end{tabular}


Appendix B. Minerals found in vesicles within different depth intervals in the Lopra-1/1A and Vestmanna-1 boreholes

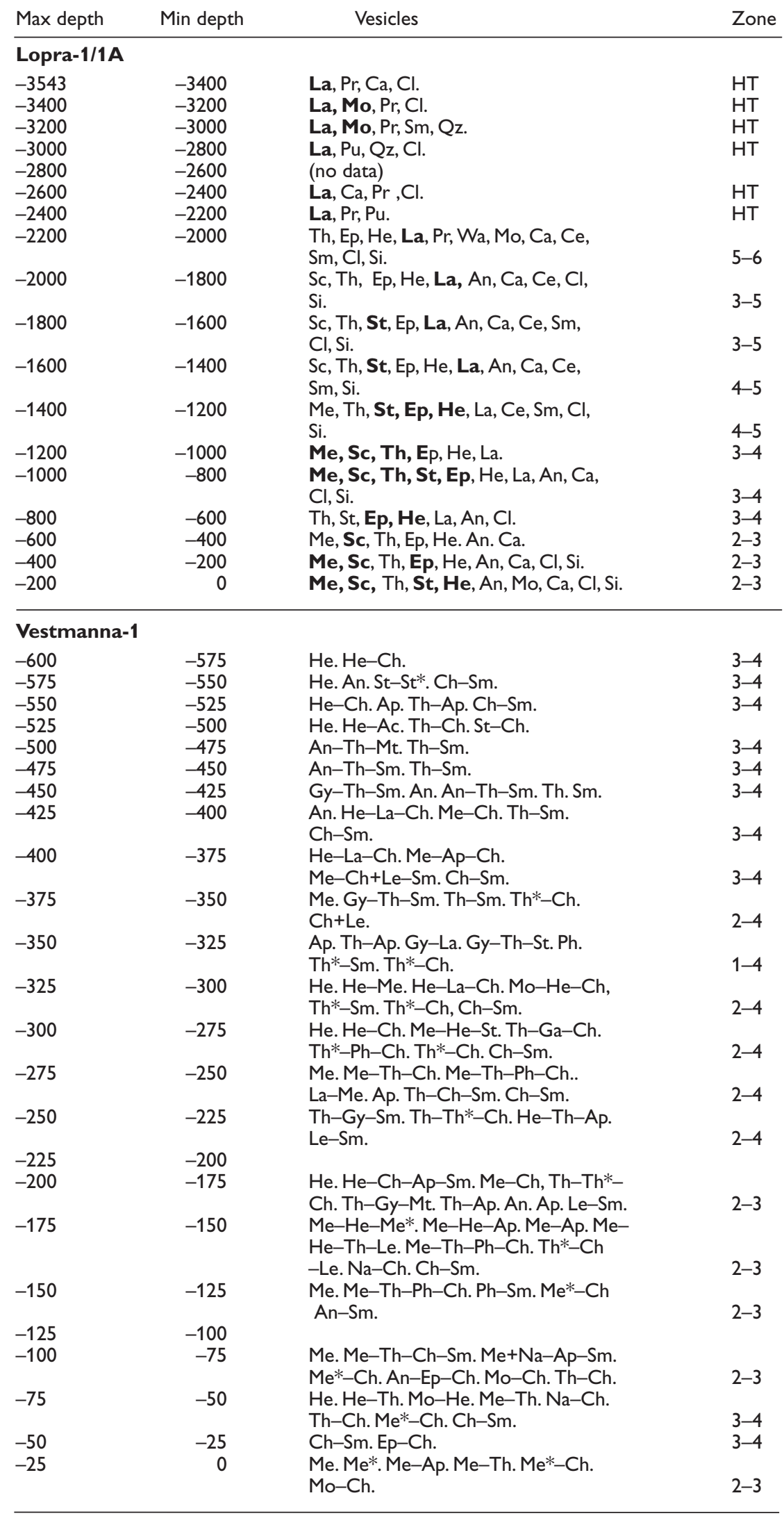

